\title{
Climatic and geologic controls on suspended sediment flux in the Sutlej River Valley, western Himalaya
}

\author{
H. Wulf ${ }^{1, *}$, B. Bookhagen ${ }^{2}$, and D. Scherler ${ }^{1}$ \\ ${ }^{1}$ Department of Earth and Environmental Science, Potsdam University, Potsdam, Germany \\ ${ }^{2}$ Department of Geography, University of California, Santa Barbara, USA \\ *now at: Remote Sensing Section, Helmholtz Centre Potsdam, GFZ German Research Center for Geosciences, \\ Telegrafenberg, 14473 Potsdam, Germany
}

Correspondence to: H. Wulf (hendrik@gfz-potsdam.de)

Received: 19 December 2011 - Published in Hydrol. Earth Syst. Sci. Discuss.: 11 January 2012

Revised: 8 June 2012 - Accepted: 22 June 2012 - Published: 20 July 2012

\begin{abstract}
The sediment flux through Himalayan rivers directly impacts water quality and is important for sustaining agriculture as well as maintaining drinking-water and hydropower generation. Despite the recent increase in demand for these resources, little is known about the triggers and sources of extreme sediment flux events, which lower water quality and account for extensive hydropower reservoir filling and turbine abrasion. Here, we present a comprehensive analysis of the spatiotemporal trends in suspended sediment flux based on daily data during the past decade (20012009) from four sites along the Sutlej River and from four of its main tributaries. In conjunction with satellite data depicting rainfall and snow cover, air temperature and earthquake records, and field observations, we infer climatic and geologic controls of peak suspended sediment concentration (SSC) events. Our study identifies three key findings: First, peak SSC events ( $\geq 99$ th SSC percentile) coincide frequently (57-80\%) with heavy rainstorms and account for about $30 \%$ of the suspended sediment flux in the semi-arid to arid interior of the orogen. Second, we observe an increase of suspended sediment flux from the Tibetan Plateau to the Himalayan Front at mean annual timescales. This sediment-flux gradient suggests that averaged, modern erosion in the western Himalaya is most pronounced at frontal regions, which are characterized by high monsoonal rainfall and thick soil cover. Third, in seven of eight catchments, we find an anticlockwise hysteresis loop of annual sediment flux variations with respect to river discharge, which appears to be related to enhanced glacial sediment evacuation during late summer. Our analysis emphasizes the importance of unconsolidated
\end{abstract}

sediments in the high-elevation sector that can easily be mobilized by hydrometeorological events and higher glacialmeltwater contributions. In future climate change scenarios, including continuous glacial retreat and more frequent monsoonal rainstorms across the Himalaya, we expect an increase in peak SSC events, which will decrease the water quality and impact hydropower generation.

\section{Introduction}

Pronounced erosion in the Himalaya delivers large amounts of sediment to the Indus and the Ganges-Brahmaputra River systems, which build up the world's two largest submarine fans in the Arabian Sea (up to 10-km thickness) (Clift et al., 2001) and the Bay of Bengal (up to 16.5-km thickness) (Curray et al., 2003), respectively. The sediment loads of these rivers (Indus: $250 \mathrm{Mt} \mathrm{yr}^{-1}$, Ganges: $520 \mathrm{Mt} \mathrm{yr}^{-1}$, Brahmaputra: $540 \mathrm{Mtyr}^{-1}$ ) rank among the highest in the world and contribute $\sim 10 \%$ to the global sediments reaching the oceans (Milliman and Syvitski, 1992). Knowledge of the magnitude and distribution of orogenic erosion rates as well as the operating processes is crucial for understanding how these landscapes evolve (Molnar and England, 1990; Small and Anderson, 1995) and how erosion might affect active tectonics (Burbank et al., 1996; Clift et al., 2008; Thiede et al., 2004, 2009; Wobus et al., 2005) and global climatic changes (Raymo et al., 1988; Raymo and Ruddiman, 1992). Furthermore, quantifying the spatiotemporal patterns and variation of fluvial sediment flux is important, because it affects 
the lifetime of hydropower reservoirs and abrasion of hydropower turbines (e.g. Singh et al., 2003).

High topographic relief, steep river profiles, and elevated stream power all indicate high erosion rates throughout the Himalaya (Finlayson et al., 2002; Vance et al., 2003). Particularly the eastern and western syntaxes are areas of high exhumation and erosion (1-10 $\mathrm{mm} \mathrm{yr}^{-1}$ ) (Burbank et al., 1996; Burg et al., 1998; Finnegan et al., 2008; Stewart et al., 2008; Zeitler et al., 2001). In contrast, erosion rates on the orographically shielded Tibetan Plateau are significantly lower $\left(<0.03 \mathrm{~mm} \mathrm{yr}^{-1}\right)$, due to lower rainfall amounts and lower topographic relief (Lal et al., 2003). However, several studies suggest that, during active monsoon phases, strong convective cells can migrate across the orographic barrier and result in heavy rainfall events, which can mobilize enormous amounts of sediment in the orogen's interior (e.g. Bookhagen, 2010; Bookhagen et al., 2005; Craddock et al., 2007; Wulf et al., 2010). Overall, the influence of monsoonal precipitation versus tectonic forcing on Himalayan landscape evolution remains debated throughout different timescales and orogenic compartments (e.g. Burbank et al., 2003; Clift et al., 2008; Galy and France-Lanord, 2001; Hodges et al., 2004; Thiede et al., 2004, 2009).

Long-term $\left(>10^{3} \mathrm{yr}\right)$ rates of erosion and models of landscape evolution are typically based on thermochronological (e.g. Reiners et al., 2005) and cosmogenic nuclide data (e.g. Bierman, 1994; Bookhagen and Strecker, 2012; von Blanckenburg, 2005), but these data do not distinguish between different erosion processes and their variability. More direct measurements of fluvial sediment yields, spanning years to decades, can be inferred from sediment accumulation rates in reservoirs (sediment trapping), or from measurements of suspended sediment and bedload fluxes in rivers (sediment gauging) (Meade, 1988; Wulf et al., 2010). Although fluvial sediment measurements do not reliably record low-frequency, high-intensity events and rarely include the bedload fraction, they provide valuable insights into the behavior of rivers and their coupling to tectonics, weather and climate (e.g. Wolman and Miller, 1960). This coupling between climate and rivers also elucidates the impact of climate change on surface erosion and fluvial sediment flux, because increasing temperatures cause pronounced environmental changes in the Himalayan region (IPCC, 2007).

In the western Himalaya, recent increases in air temperatures (Shekhar et al., 2010) are likely causing the retreat of most glaciers (ca. 20-50 $\mathrm{m} \mathrm{yr}^{-1}$ ) over the past decades (Bhambri and Bolch, 2009; Scherler et al., 2011a). Retreating glaciers expose unstable paraglacial landscapes, which are highly susceptible to erosion processes driven by glacial runoff and rainfall (e.g. Meigs et al., 2006). Furthermore, the increase in air temperatures increases the flood risk imposed by glacial lakes and causes widespread permafrost degradation, which in turn decreases the slope stability and enhances erosion processes (Cheng and $\mathrm{Wu}, 2007$; Lawrence and Slater, 2005; Zhao et al., 2004). Likewise, large areas in the western Himalaya experience reduced snow cover (Shekhar et al., 2010) as more precipitation falls in the form of rain. Therefore, recent climate change is likely to enhance surface erosion processes, especially in glacial and periglacial regions.

In this study, we analyze daily river discharge and suspended sediment concentration (SSC) data from the Sutlej River Valley in the western Himalaya to study the sediment flux (i.e. discharge multiplied by SSC) characteristics in different geologic and climatic regions. We compare the sediment flux data from four sites along the main stem of the Sutlej and from four of its largest tributaries with remotely sensed rainfall and snow cover data, as well as air temperature and earthquake records to investigate the climatic and geologic controls on low-frequency, high-magnitude sediment discharges. Previous research shows that such peak events often account for a large fraction of the sediment budget (e.g. Barnard et al., 2001; Bookhagen et al., 2005; Kirchner et al., 2001; Wulf et al., 2010). In a final step, we compare the new data with published sediment flux data from across the Himalaya to identify spatial patterns and first-order controls on sediment transport.

\section{Geographic, climatic, and geologic setting}

\subsection{Geographic setting}

The Sutlej River is the largest tributary of the Indus River and drains the third largest catchment area in the Himalaya (ca. $55000 \mathrm{~km}^{2}$ above $500 \mathrm{~m}$ a.s.l. - above sea level). Approximately two-thirds of this area is located in China and drains the Zhada Basin (cf. Fig. 1, Sutlej River subcatchment number 5), which stretches NW-SE between the southern edge of the Tibetan Plateau and the Mount Kailash Range. To the west, the Indian part of the Sutlej Valley covers a wide range of elevations between the Indo-Gangetic Plains (400 $\mathrm{m}$ a.s.l) and the Himalayan Crest (6400 $\mathrm{m}$ a.s.l.) (Fig. 1). The catchment-average altitude is $4400 \mathrm{~m}$ a.s.l., and more than $80 \%$ of the catchment area is located at $>4000 \mathrm{~m}$ a.s.l. with virtually no vegetation cover (Fig. 1a). The lower part of the catchment area $(<4000 \mathrm{~m}$ a.s.l. $)$ is located at the monsoon-impacted southern front of the Himalaya, where vegetation is lush and dense. Therefore, the primary land cover in the Sutlej Valley is bare ground $(81.2 \%)$, followed by trees and shrubs $(7.2 \%)$, cultivated areas $(6.8 \%)$, glaciers $(3.7 \%)$, and lakes $(1.1 \%)$ (FAO, 2009). Developed soils cover only a small fraction $(<15 \%)$, mostly in the lower part of the Sutlej Valley. Glacial cover is particularly dense at the Himalayan Crest, where snowfall is highest (e.g. Singh and Kumar, 1997). As a result, river runoff is dominated by snow- and glacial-melt from the high, orographically shielded Himalayan Crest and is comparable in magnitude to the Himalayan Front, where it is dominated by monsoonal rainfall (Bookhagen and Burbank, 2010). 


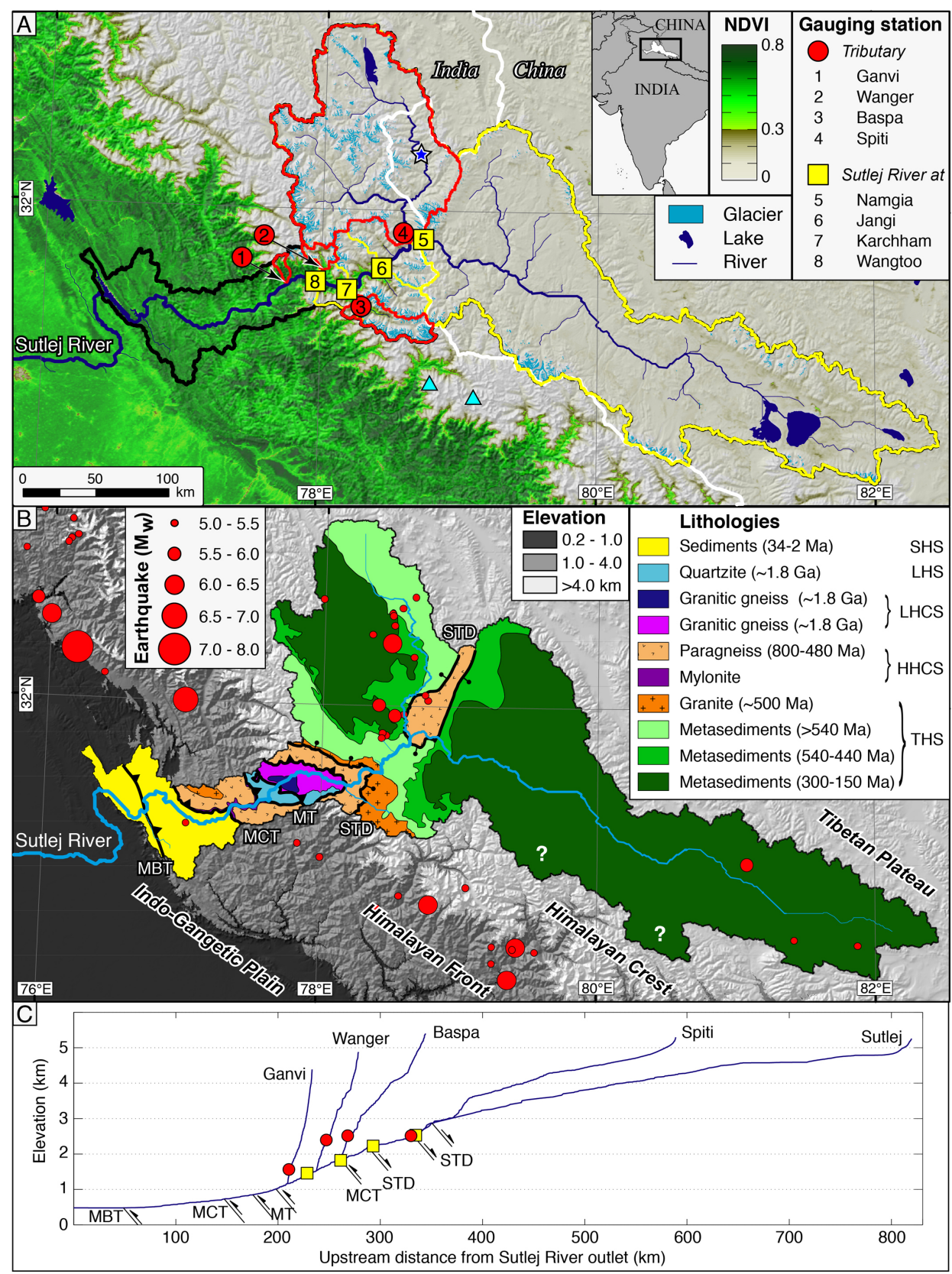

Fig. 1. (A) Map of the study area, showing the normalized difference vegetation index (NDVI) based on MODIS data (Huete et al., 2002), draped over a shaded relief map, and overlain by glaciers, lakes, and the Sutlej River network. Numbers denote gauging stations where river discharge and suspended sediment concentration were measured. The Baspa River (no. 3) joins the Sutlej River downstream of Karchham (nr. 7). The corresponding upstream areas of the Sutlej River and its tributaries are indicated in red and yellow, respectively. The star marks the location of the temporary Parechu Lake, and the triangles indicate the locations of the Dokriani (east) and Gangotri (west) glaciers. The glacial shapefiles are based on Landsat classification data of debris-free ice and manual delineation of debris-covered glacial areas in Google Earth. (B) Geologic units and major tectonic structures (modified after Thiede et al., 2004; Vannay et al., 2004; Webb et al., 2011) within the study area together with earthquake locations (http://www.iris.washington.edu) (Table A2). Lithologies are grouped into the Sub-Himalaya Sequence (SHS), Lesser Himalayan Sequence (LHS), Lesser Himalayan Crystalline Sequence (LHCS), Higher Himalayan Crystalline Sequence (HHCS), and Tethyan Himalayan Sequence (THS). Major tectonic faults along the Sutlej River are indicated by the following abbreviations: MBT (Main Boundary Thrust), MCT (Main Central Thrust), MT (Munsiari Thrust), STD (South Tibetan Detachment). Surrounding areas show elevation draped over a shaded-relief map to differentiate different orogenic compartments. (C) Longitudinal river profile of the Sutlej River and its tributaries analyzed in this study. Red circles and yellow squares denote gauging station locations as indicated in (A). 
Throughout this study, we distinguish between the Himalayan Front, the Himalayan Crest, and the Tibetan Plateau region based on topographic and climatic characteristics (Fig. 1b). The Himalayan Front marks the area between the Indo-Gangetic Plains and the high Himalayan peaks and is characterized by high monsoonal rainfall and dense vegetation at elevations $<3500 \mathrm{~m}$. We consider the Ganvi River with its most frontal position to represent fluvial sediment flux characteristics at the Himalayan Front, although its river catchment is located in close proximity to the Himalayan Crest region (Fig. 1). Because of the high topographic relief and its windward exposition south of the main orographic barrier, the Ganvi catchment receives substantial snow- and rainfall amounts. The Himalayan Crest region comprises the high mountain peaks of the Himalaya and leeward areas that are characterized by high relief, abundant snowfall, a high degree of glaciation, and sparse vegetation. The Baspa, Wanger, and the southern part of the Spiti catchment belong to the Himalayan Crest region. High elevations, low relief and almost no vegetation due to arid climatic conditions characterize the Tibetan Plateau region, which comprises the northern part of the Spiti catchment and the Sutlej catchment upstream of Namgia (i.e. the Zhada Basin).

\subsection{Climatic and geologic setting}

Precipitation in the western Himalaya has pronounced seasonal and spatial variations (Bookhagen and Burbank, 2010). Most snowfall occurs between December and March and increases with elevation (Singh and Kumar, 1997; Wulf et al., 2010). From mid-July to mid-September, the Indian monsoon accounts for intense rainfall, which is focused at elevations of $900 \pm 400 \mathrm{~m}$ and $2100 \pm 300 \mathrm{~m}$ a.s.l. at the southern Himalayan Front (Bookhagen and Burbank, 2006). The Higher Himalaya acts as an orographic barrier that inhibits most monsoonal moisture to migrate northward into the orogen and therefore creates a steep orographic rainfall gradient. Rainfall decreases from $>2 \mathrm{~m}$ at the front to $<0.2 \mathrm{~m}$ in the interior of the orogen over a horizontal distance of $<100 \mathrm{~km}$ (Wulf et al., 2010). The highly seasonal precipitation results in peak river discharges and sediment fluxes during the summer season and orographic processes result in pronounced spatial differences in runoff magnitude.

The rocks in the study area can be subdivided into several contrasting units, which are bounded by major north-dipping tectonic fault systems that run parallel along-strike the mountain belt (e.g. Burchfiel et al., 1992; Fuchs, 1975; Gansser, 1964; Heim and Gansser, 1939; Hodges, 2000). From southwest to northeast, these units comprise (a) the Sub-Himalaya, which contains detrital sediments derived from erosion of the orogen (Vannay et al., 2004); (b) the Lesser Himalaya Sequence (LHS), which mainly consists of massive quartzarenites intruded by basalts (Miller et al., 2000); (c) the medium- to high-grade metamorphic sequence of the Lesser Himalayan Crystalline Sequence (LHCS), which consists of mylonitic micaschists, granitic gneisses with minor metabasites and quartzites (Vannay and Grasemann, 1998); (d) the Higher Himalaya Crystalline Sequence (HHCS), which is composed of amphibolite facies to migmatitic paragneisses with minor metabasites, calc-silicate gneisses, and granitic gneisses often intruded by granitic plutons (Thiede et al., 2004, 2006; Vannay and Grasemann, 1998); and (e) the weakly metamorphosed sediments of the Tethyan Himalayan Sequence (THS), which consist of metapelites and metapsammites that comprise the cover sediments of the former Indian continental margin (Vannay et al., 2004).

The continuous northeastward movement of India with respect to Eurasia at a present rate of ca. $35 \mathrm{~mm} \mathrm{yr}^{-1}$ (Larson et al., 1999; Wang et al., 2001) causes considerable seismic activity in the Himalaya (Bilham et al., 2001). During the past five decades, 20 earthquakes with magnitude $\geq 5$ were recorded in the Sutlej Valley (Fig. 1a). Whereas large NWSE shortening earthquakes at the Himalayan Front are related to the underthrusting of India beneath Eurasia, shallow $(<15 \mathrm{~km})$ earthquakes in the Himalayan Crest and Tibetan Plateau regions mainly are documented with ongoing E-W extension (Hintersberger et al., 2010).

\section{Data sets and methods}

In the Indian part of the Sutlej Valley, several hydropower companies operate a dense network of gauging stations that measure river discharge and suspended sediment concentrations (SSC). River discharge measurements are based on stage-discharge rating curves, which are annually recalculated during low-flow conditions in winter because of channel bed changes. SSC sampling is generally done at the water surface and close to the riverbank. Given the high velocity and turbulence of the streams, we assume a high degree of sediment mixing and that the SSC samples are therefore representative of the entire water column. In our analysis, river discharge and SSC data represent the daily average of usually two measurements: one in the early morning and one during late afternoon. In the Baspa River and the Sutlej River at Wangtoo, measurements are conducted on a 6-hourly and hourly basis, respectively. Despite the high sampling frequency of the Sutlej River at Wangtoo, we had only access to the daily minimum and maximum SSC data, of which we calculated the arithmetic mean for our analysis. Year-round SSC sampling has been conducted in the Wanger River, the Baspa River and the Sutlej River at Wangtoo and Jangi. Gaps in SSC data set exist for the Wanger River on Sundays and national holidays. Further variable interruptions at all gauging stations are related to extreme flood events or local operational failures. Due to the pronounced annual cycle in sediment flux, SSC sampling in the Spiti River, the Sutlej River at Namgia and Karchham is constrained to the summer halfyear (May to October) or to major parts of this time period when SSC is above the detection level. Interpretation of the 
Table 1. Explanation of acronyms and abbreviations used in this study. $\mathrm{SSL}_{\mathrm{eff}}, \mathrm{SSY}_{\mathrm{eff}}$, and $R_{\mathrm{eff}}$ refer to the summer half-year (May to October).

\begin{tabular}{llll}
\hline Acronym & Explanation & Unit & Grouping \\
\hline$Q$ & river discharge & $\mathrm{m}^{3} \mathrm{~s}^{-1}$ & Hydrologic terms \\
SSC & suspended sediment concentration & $\mathrm{g} \mathrm{l}^{-1}$ & \\
$\mathrm{SSL}_{\mathrm{eff}}$ & effective suspended sediment load & $\mathrm{t} \mathrm{summer}^{-1}$ & \\
SSY $_{\text {eff }}$ & effective suspended sediment yield & $\mathrm{t} \mathrm{summer}^{-1} \mathrm{~km}^{-2}$ & \\
$R_{\mathrm{eff}}$ & effective runoff & & \\
PF & Parechu Flood & & \\
\hline SHS & Sub-Himalaya Sequence & & \\
LHS & Lesser Himalayan Sequence & & \\
LHCS & Lesser Himalayan Crystalline Sequence & \\
HHCS & Higher Himalayan Crystalline Sequence & Tectonic structures \\
THS & Tethyan Himalayan Sequence & & \\
\hline MBT & Main Boundary Thrust & & \\
MCT & Main Central Thrust & & \\
MT & Munsiari Thrust & & Satellite missions \\
STD & South Tibetan Detachment & Index \\
\hline MODIS & Moderate Resolution Imaging Spectroradiometer & & \\
TRMM & Tropical Rainfall Measuring Mission & & \\
\hline NDVI & Normalized Difference Vegetation Index & & \\
\hline
\end{tabular}

sediment flux data in the Ganvi tributary needs to be done with caution, because SSC measurements during the years 2003 and 2006 to 2008 cover less than 90 days of the summer half-year (Table A1). A detailed overview of the available data set lengths during the summer half-year and the respective river discharge, SSC, SSL and suspended sediment yield (SSY) measurements is presented in Table A1.

Following Wolman and Miller (1960), we define effective river discharge ( $\left.Q_{\text {eff }}\right)$ as the discharge that transports the bulk of suspended sediment, which occurs during summer halfyear (Table 1). Analyzing sediment flux during the summer season allows for a better comparison between all gauging stations, as this time period integrates most measurements. We account for days without data during this time period by calculating the proportionality between the length of the measurement period ( $d \leq 184$ days) and the length of the summer half-year (184 days). To prevent miscalculations of the seasonal budget resulting from too few measurements, we excluded summer half-years with less then 50 days of combined SSC and river discharge measurements (Table A1). We use daily measurements of river discharge, $Q\left(\mathrm{~m}^{3} \mathrm{~s}^{-1}\right)$, and suspended sediment concentration, SSC $\left(\mathrm{g}^{-1}\right)$, during the summer half-year to calculate the effective suspended sediment load, SSL eff $\left(\mathrm{t}_{\text {summer }}{ }^{-1}\right)$, and the effective suspended sediment yield, $\mathrm{SSY}_{\text {eff }}\left(\mathrm{t} \mathrm{km}^{-2}\right.$ summer $\left.^{-1}\right)$, according to

$\mathrm{SSL}_{\text {eff }}=\frac{\sum_{i=1}^{d}(Q(i) \cdot \operatorname{SSC}(i)) \cdot 184}{d}$
$\mathrm{SSY}_{\mathrm{eff}}=\mathrm{SSL}_{\mathrm{eff}} / A$

where $A$ is the catchment area $\left(\mathrm{km}^{2}\right)$. SSY eff represents the specific sediment transport of a certain sediment mass during the summer half-year within an associated watershed area. As indicated by the continuous SSC and river discharge data set of the Baspa River and the Sutlej River at Wangtoo, the SSL during the summer half-year accounts for more than $90 \%$ of the mean annual sediment budget. Similar relations have been found in rivers draining the southeastern Tibetan Plateau (Henck et al., 2010). Consequently, we assume that the SSL during the winter half-year (November to April) is insignificant compared to the summer half-year (May to October) and equates effective SSL/SSY with annual SSL/SSY. In order to compare the specific river runoff among different catchments, we convert daily $Q$ during the summer half-year to part of the effective runoff, $R_{\text {eff }}$ (m summer ${ }^{-1}$ ), according to

$R_{\mathrm{eff}}=\frac{\sum_{i=1}^{d} Q(i) \cdot 184}{A \cdot d}$.

To investigate potential links between extreme events of suspended sediment flux and rainfall, we use the TRMM (Tropical Rainfall Measuring Mission) product 3B42, which has a spatial resolution of $0.25^{\circ} \times 0.25^{\circ}(\sim 30 \mathrm{~km} \times 30 \mathrm{~km})$ and a temporal resolution of $3 \mathrm{~h}$. This data set combines microwave and infrared rain-rate estimates, derived from sensors onboard one geosynchronous and several low-Earth 

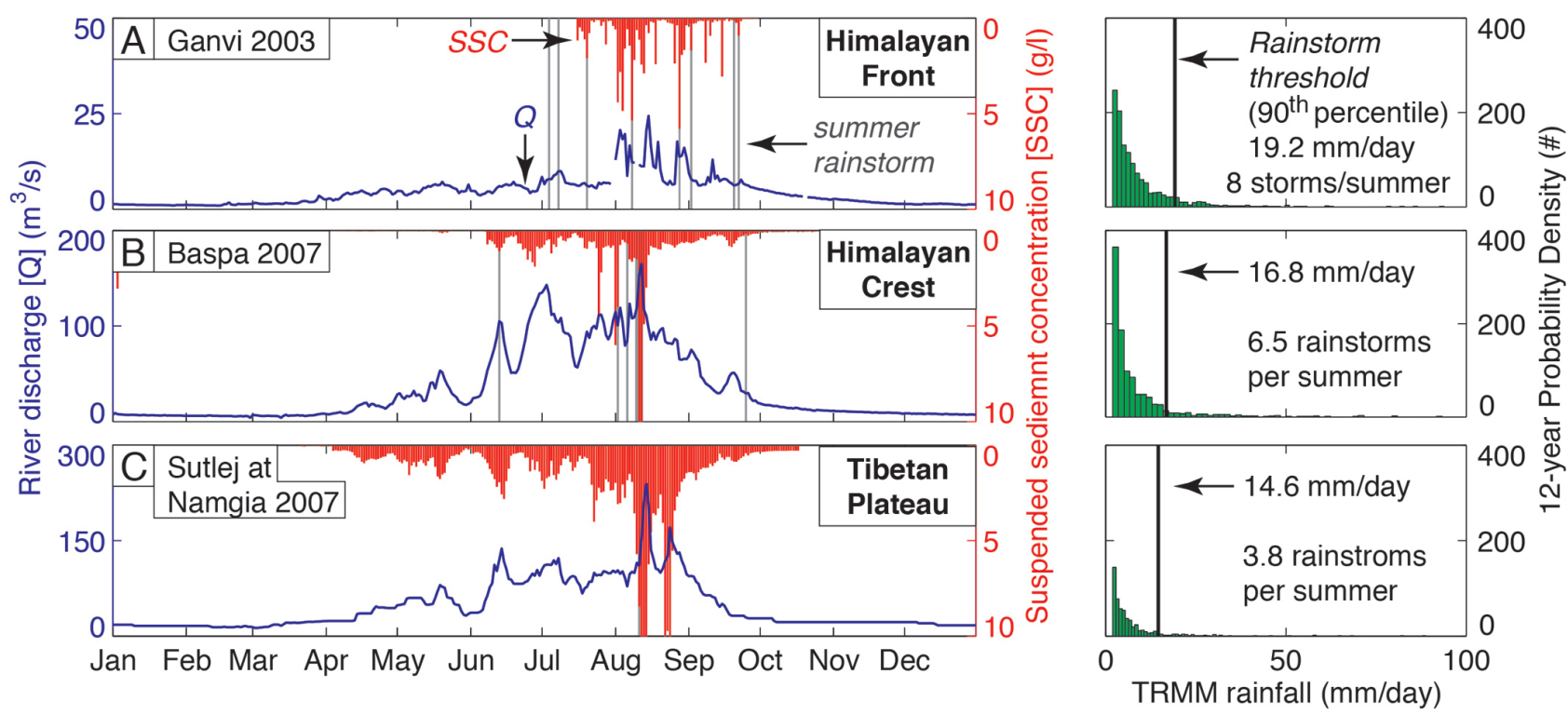

Fig. 2. Annual course of river discharge $(Q)$ and suspended sediment concentration (SSC) underlain by summer rainstorms (May-October) in different orogenic regions represented by the Ganvi tributary during the year 2003 (A), the Baspa tributary during 2007 (B), and the Sutlej River at Namgia during 2007 (C). Panels on the right show the catchment-respective probability density (number of occurrences) of wet rainfall days $\geq 2 \mathrm{~mm}$ in $1 \mathrm{~mm}^{-1 a y}{ }^{-1}$ bins as taken from the 12-yr TRMM 3B42 data set. Note that SSC data in (A) are restricted to 77 days from mid-July to mid-September.

orbit satellites, which have been rescaled with monthly raingauge data (Huffman et al., 2007). The recently published APHRODITE rainfall data set (Yatagai et al., 2009) has been shown to be a good rainfall indicator in the central Himalaya, where data density is high (Andermann et al., 2011). However, in the western Himalaya, rainfall stations are sparse, especially in the upper Sutlej area. Hence, we here rely on the satellite-derived rainfall product TRMM 3B42, which is particularly well suited to detect heavy rainfall events due to its high temporal resolution.

Rainfall in the 90th percentile of its distribution has been previously associated with extreme rainfall events (e.g. Bookhagen, 2010; Cayan et al., 1999; Krishnamurthy et al., 2009). Here, we define rainstorms as days during which rainfall exceeds the 90th percentile of all days with rainfall $\geq 2 \mathrm{~mm} \mathrm{day}^{-1}$ during the 12 -yr rainfall data set $(1998$ to 2009) and within each catchment (Fig. 2). Based on the same approach, we define peak SSC days as days in which the SSC exceeds the 99th percentile of the entire SSC data set from one catchment. In other words, peak SSC days correspond to the uppermost $1 \%$ magnitude of the SSC data set. In case of several successive peak SSC days, we assume a single trigger mechanism and refer to peak SSC events. Such peak SSC events have lengths of 2-7 days in our data and are generally characterized by an abrupt increase in SSC followed by a gradual decrease.

To study the control of snow and glacial melt water runoff on sediment flux, we further use daily fractional snow cover observations that are derived from the MODIS (Moderate
Resolution Imaging Spectroradiometer) instrument onboard the Terra and Aqua satellites of the NASA Earth Observation System (Hall et al., 1995, 2002). These daily snow products (MOD10A1 and MYD10A1) exhibit a higher temporal resolution and more spatial detail as compared to the upper level 8-day snow products (MOD10A2 and MYD10A2) but exhibit cloud cover data gaps. Comparison of daily MODIS snow products with ground-based snow measurements in the western US and Austria has yielded accuracies of 94-95\% (Klein and Barnett, 2003; Parajka and Blöschl, 2006).

We reduced cloud-cover-related data gaps in our study area (Fig. 1) from $42.1 \pm 27.8 \%$ to $25.8 \pm 21.6 \%$ by combining Terra and Aqua observations from the same day (Gafurov and Bárdossy, 2009). Furthermore, we corrected for artifacts introduced by large viewing angles and other systematic errors with spline interpolation on the fractional snow cover time series by following the methodology proposed by Dozier et al. (2008). The smoothing splines are weighted based on the sensor zenith angle, which is provided in the MODIS surface reflectance product MOD09GA (Dozier et al., 2008). Finally, we filled all remaining data gaps by piecewise linear interpolation (Fritsch and Carlson, 1980).

In order to assess the direct impact of earthquakes on suspended sediment flux, we used seismic records from within our study area (Fig. 1b) with a surface magnitude larger than five that we obtained from the Incorporated Research Institutions for Seismology (http://www.iris.edu) (Table A2). During the period of sediment flux measurements (2001-2009), 22 earthquakes $(M>5)$ were detected and used to include 
Table 2. Topographic, climatic and hydrological characteristics of the studied watersheds. Locations of the catchments are indicated in Fig. 1. The snow-covered area, the TRMM 3B42 rainfall magnitudes, and the NDVI represent the annual mean of each watershed. Summer indicates the period from May to October. Both the suspended sediment concentration (SSC) and the effective suspended sediment yield (SSY eff $_{\text {) }}$ refer to the summer half-year.

\begin{tabular}{|c|c|c|c|c|c|c|c|c|c|c|c|c|}
\hline \multirow[t]{4}{*}{ Catchments } & \multicolumn{4}{|c|}{ Topography } & \multicolumn{4}{|c|}{ Climate } & \multicolumn{4}{|c|}{ Hydrology } \\
\hline & \multirow{3}{*}{$\begin{array}{l}\text { Area } \\
\left(\mathrm{km}^{2}\right)\end{array}$} & \multicolumn{2}{|c|}{ Elevation } & \multirow{3}{*}{$\begin{array}{l}\text { Relief } \\
(\mathrm{km} / \\
5 \mathrm{~km})\end{array}$} & \multirow{3}{*}{$\begin{array}{r}\text { Ice } \\
\text { area } \\
(\%)\end{array}$} & \multirow{3}{*}{$\begin{array}{l}\text { Snow } \\
\text { area } \\
(\%)\end{array}$} & \multirow{3}{*}{$\begin{array}{c}\text { Rain } \\
\text { TRMM } \\
\left(\mathrm{m} \mathrm{yr}^{-1}\right)\end{array}$} & \multirow{3}{*}{$\begin{array}{l}\text { Vege- } \\
\text { tation } \\
\text { NDVI }\end{array}$} & \multirow{2}{*}{\multicolumn{2}{|c|}{$\begin{array}{c}\text { Runoff } \\
\text { summer }\end{array}$}} & \multirow{3}{*}{$\begin{array}{c}\mathrm{SSC} \\
\text { mean } \\
\left(\mathrm{g} \mathrm{l}^{-1}\right)\end{array}$} & \multirow{3}{*}{$\begin{array}{r}\mathrm{SSY}_{\mathrm{eff}} \\
\left(\mathrm{t} \mathrm{km}^{-2}\right. \\
\left.\text { summer }^{-1}\right)\end{array}$} \\
\hline & & $\min$ & $\max$ & & & & & & & & & \\
\hline & & $(\mathrm{km})$ & $(\mathrm{km})$ & & & & & & $\left(\mathrm{m} \mathrm{yr}^{-1}\right)$ & $(\%)$ & & \\
\hline \multicolumn{13}{|c|}{ Tributaries } \\
\hline Ganvi & 117 & 1.6 & 5.6 & 2.58 & 3.7 & 25.8 & 1.12 & 0.39 & 1.27 & 78.3 & 0.93 & 1507 \\
\hline Wanger & 264 & 2.5 & 5.7 & 2.24 & 17.2 & 54.1 & 0.74 & 0.11 & 1.67 & 85.4 & 0.29 & 614 \\
\hline Baspa & 989 & 2.5 & 6.4 & 2.21 & 24.0 & 54.0 & 0.93 & 0.09 & 1.14 & 89.5 & 0.80 & 1717 \\
\hline Spiti & 12477 & 2.6 & 6.7 & 1.68 & 6.7 & 37.4 & 0.36 & 0.03 & 0.26 & 86.9 & 1.45 & 499 \\
\hline \multicolumn{13}{|c|}{ Sutlej River } \\
\hline at Namgia & 30950 & 2.6 & 7.2 & 0.93 & 1.8 & 19.8 & 0.38 & 0.08 & 0.06 & 85.1 & 2.59 & 223 \\
\hline at Jangi & 44738 & 2.2 & 7.2 & 1.21 & 3.6 & 25.6 & 0.39 & 0.07 & 0.13 & 81.5 & 1.85 & 302 \\
\hline at Karchham & 46291 & 1.9 & 7.2 & 1.22 & 3.6 & 25.7 & 0.39 & 0.07 & 0.16 & 85.3 & 2.37 & 556 \\
\hline at Wangtoo & 48316 & 1.5 & 7.2 & 1.27 & 4.1 & 26.5 & 0.41 & 0.07 & 0.20 & 85.9 & 2.20 & 615 \\
\hline
\end{tabular}

or exclude earthquakes as a potential source for peak SSC events based on their timings.

\section{Results}

\subsection{Relationship between river discharge and suspended sediment concentration}

River discharge and SSC are both characterized by a pronounced seasonality (Fig. 2). During the winter half-year, most precipitation above $2000 \mathrm{~m}$ a.s.l. falls in the form of snow that confines river discharge to low flow conditions, which correlate with low SSC $\left(<0.5 \mathrm{~g} \mathrm{l}^{-1}\right)$. During the summer half-year, river discharge increases along with rainfall, snow- and glacial melt, which results in increased stream power and enhanced transport capacity that elevates SSC typically above $0.5 \mathrm{~g} \mathrm{l}^{-1}$. In the Baspa River and the Sutlej River at Wangtoo, the suspended sediment load (SSL) during the summer half-year accounts for $96.5 \%$ and $91.6 \%$ of the annual SSL, respectively. Overall, the summer half-year accounts for more than $80 \%$ of the annual river discharge budget and more than $90 \%$ of the annual SSL budget (Table 2).

To assess the spatial variability of river discharge and SSC, we cross-correlate all gauging sites (Table 3). River discharge is highly correlated $\left(r^{2}>0.8\right)$ among all stations in the Himalayan Crest and Tibetan Plateau regions, indicating similar nivo-glacial (i.e. dominated by snow- and glacial melt) runoff regimes, whereas the smallest, mostly rain-fed Ganvi tributary at the Himalayan Front exhibits the weakest correlation with all other stations. The overall lower correlation among all SSC gauging stations compared to river discharge indicates a higher spatial variability in SSC, which is most likely due to variable response times between small and large catchments. The pronounced correlation $\left(r^{2} \geq 0.78\right)$ of SSC from neighboring stations along the Sutlej River (bold numbers in Table 3) underpins our confidence in the data.

In all catchments, we find a positive correlation between daily river discharge and daily SSC (Fig. 3), i.e. the higher the river discharge, the higher the sediment concentration. This correlation suggests increasing mobilization of transiently stored sediment along the river as the river discharge increases. However, some days are characterized by extraordinary high SSC values that occasionally range 1-2 orders of magnitude above the seasonal average and therefore exhibit large residuals from the fitted Q-SSC relationship (Fig. 3). Such peak SSC days ( $\geq 99$ th SSC percentile) occur predominantly during July and August, i.e. the peak period of the Indian summer monsoon, when river discharge is highest due to additional snow and glacial melts. Therefore, peak SSC days are generally associated with a high sediment load. However, some peak SSC days also occur in June or September; but due to the generally lower runoff, they leave only a low imprint on the overall sediment budget (Fig. 4).

\subsection{Peak suspended sediment concentration events}

Peak SSC days occur almost annually in most catchments and can be traced in many cases throughout the Sutlej River network (Fig. 4). Peak SSC days during the observation period (2001-2009) appear to be concurrent with rainstorms, a lake outburst flood, and extreme melt events. In contrast, none of the peak SSC days can be related to an earthquake with a magnitudes $M_{\mathrm{S}} \geq 5$ (cf. Table A2). Between 2005 and 
Table 3. Correlation of daily river discharge (top) and daily suspended sediment concentration (bottom) among different gauging sites. Neighboring stations along the Sutlej, which are expected to correlate strongly, are marked bold.

\begin{tabular}{lclllllll}
\hline $\begin{array}{l}\text { River discharge } \\
\text { (coefficient of } \\
\text { determination) }\end{array}$ & Ganvi & Wanger & Baspa & Spiti & $\begin{array}{l}\text { Sutlej at } \\
\text { Namgia }\end{array}$ & $\begin{array}{l}\text { Sutlej at } \\
\text { Jangi }\end{array}$ & $\begin{array}{l}\text { Sutlej at } \\
\text { Karchham }\end{array}$ & $\begin{array}{l}\text { Sutlej at } \\
\text { Wangtoo }\end{array}$ \\
\hline Ganvi & 1 & 0.57 & 0.75 & 0.77 & 0.77 & 0.62 & 0.60 & 0.79 \\
Wanger & - & 1 & 0.91 & 0.84 & 0.86 & 0.95 & 0.84 & 0.92 \\
Baspa & - & - & 1 & 0.91 & 0.85 & 0.95 & 0.93 & 0.96 \\
Spiti & - & - & - & 1 & 0.81 & 0.95 & 0.91 & 0.92 \\
Sutlej (Namgia) & - & - & - & - & 1 & $\mathbf{0 . 9 5}$ & 0.93 & 0.91 \\
Sutlej (Jangi) & - & - & - & - & - & 1 & $\mathbf{0 . 9 8}$ & 0.98 \\
Sutlej (Karchham) & - & - & - & - & - & - & 1 & $\mathbf{0 . 9 7}$ \\
Sutlej (Wangtoo) & - & - & - & - & - & - & - & 1 \\
\hline Suspended & Ganvi & Wanger & Baspa & Spiti & Sutlej at & Sutlej at & Sutlej at & Sutlej at \\
sediment conc. & & & & & Namgia & Jangi & Karchham & Wangtoo \\
\hline Ganvi & 1 & 0.43 & 0.17 & 0.32 & 0.08 & 0.38 & -0.13 & 0.15 \\
Wanger & - & 1 & 0.31 & 0.56 & 0.49 & - & 0.80 & 0.41 \\
Baspa & - & - & 1 & 0.49 & 0.41 & 0.59 & 0.37 & 0.51 \\
Spiti & - & - & - & 1 & 0.64 & 0.92 & 0.66 & 0.82 \\
Sutlej (Namgia) & - & - & - & - & 1 & $\mathbf{0 . 8 9}$ & 0.73 & 0.87 \\
Sutlej (Jangi) & - & - & - & - & - & 1 & $\mathbf{0 . 7 9}$ & 0.82 \\
Sutlej (Karchham) & - & - & - & - & - & - & 1 & $\mathbf{0 . 7 8}$ \\
Sutlej (Wangtoo) & - & - & - & - & - & - & - & 1 \\
\hline
\end{tabular}
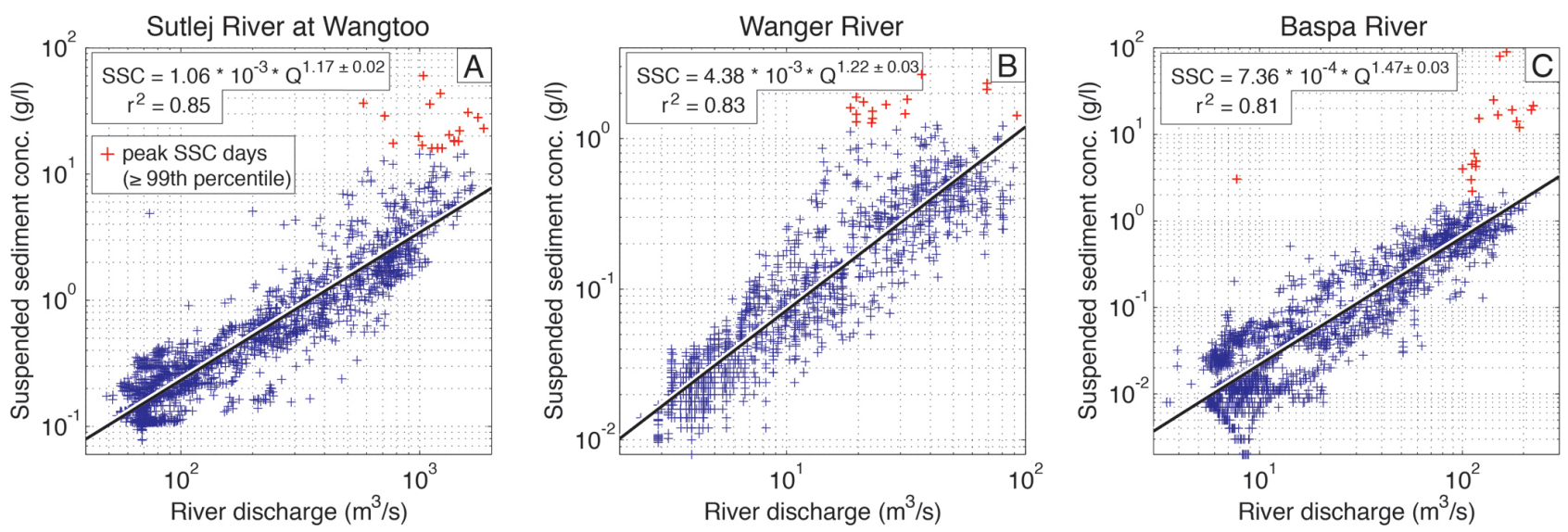

Fig. 3. Correlation of river discharge $(Q)$ and suspended sediment concentration (SSC) for the Sutlej River at Wangtoo (A), the Wanger River (B), and the Baspa River (C). These correlations are subject to seasonal variations due to hysteresis effects and high sediment-transport events and therefore not suited for sediment flux predictions. Note the different scales of the axes.

2007, we identify three major rainstorms, which last together for seven days and can be traced by several gauging stations in the Sutlej catchment. Their widespread simultaneous occurrence indicates that rainstorms can affect large areas.

The sediment amount transported during peak SSC events varies considerably among all catchments ranging between $5 \%$ and $62 \%$ of the overall $\mathrm{SSL}_{\text {eff }}$ budget. In the largest catchment area of the Sutlej River at Wangtoo, which integrates most tributary catchments, peak SSC events contribute $\sim 30 \%$ to the total suspended sediment flux (Table 4 ). In other words, river discharge transporting the uppermost $1 \%$ of the SSC data set accounts for $30 \%$ of the total suspended sediment flux. In all catchments leeward (northward) of the main orographic barrier, the 90th SSC percentile accounts for more than $50 \%$ of the total suspended sediment flux (Fig. 5).

While many of the peak SSC events occur on the same day as rainstorms, delays of up to 1 or 2 days can be observed (Fig. 6). Because these delays exclusively occur in the largest catchments, we suspect that they are related to routing of the discharge from the source areas to the gauging 
Table 4. Peak suspended sediment concentration (SSC) events and their relation to rainstorms (>90th percentile), the Parechu Flood, and meltwaters. Peak SSC events combine successive peak SSC days ( $\geq 99$ th SSC percentile). Dashes indicate that no records were obtained during the Parechu Flood. Note the variable length of the records and that SSC records of the Ganvi River, Spiti River, and the Sutlej River at Namgia and Karchham refer to the summer half-year only.

\begin{tabular}{|c|c|c|c|c|c|c|c|c|c|c|c|c|c|}
\hline \multirow[t]{2}{*}{ River } & \multirow{2}{*}{$\begin{array}{r}\text { SSC } \\
\text { record } \\
\text { length } \\
\text { (days) }\end{array}$} & \multirow{2}{*}{$\begin{array}{r}\text { 99th per- } \\
\text { centile SSC } \\
\text { threshold } \\
\left(\mathrm{g}^{-1}\right)\end{array}$} & \multirow{2}{*}{$\begin{array}{l}\text { 90th per- } \\
\text { centile rainfall } \\
\text { threshold } \\
\left(\mathrm{mm} \mathrm{day}^{-1}\right)\end{array}$} & \multirow{2}{*}{$\begin{array}{c}\text { Number of } \\
\text { peak SSC } \\
\text { events } \\
\text { (\#) }\end{array}$} & \multirow{2}{*}{$\begin{array}{r}\text { Percent } \\
\text { of SSL } \mathrm{Sff} \\
\text { budget } \\
(\%)\end{array}$} & \multicolumn{2}{|c|}{$\begin{array}{l}\text { Events } \\
\text { caused by } \\
\text { rainstorms }\end{array}$} & \multicolumn{2}{|c|}{$\begin{array}{c}\text { Event } \\
\text { caused by the } \\
\text { Parechu Flood }\end{array}$} & \multicolumn{2}{|c|}{$\begin{array}{c}\text { Events } \\
\text { caused by } \\
\text { meltwaters }\end{array}$} & \multicolumn{2}{|c|}{$\begin{array}{l}\text { Events with } \\
\text { unknown } \\
\text { trigger }\end{array}$} \\
\hline & & & & & & (\#) & $(\%)$ & (\#) & $(\%)$ & (\#) & $(\%)$ & $(\#)$ & $(\%)$ \\
\hline \multicolumn{14}{|c|}{ Tributaries } \\
\hline Ganvi & 215 & 5.5 & 19.2 & 1 & 5.6 & 1 & 100 & 0 & 0 & 0 & 0 & 0 & 0 \\
\hline Wanger & 1470 & 1.3 & 18.0 & 5 & 9.8 & 4 & 80 & 0 & 0 & 0 & 0 & 1 & 20 \\
\hline Baspa & 1867 & 2.1 & 18.5 & 7 & 61.9 & 4 & 57 & 0 & 0 & 1 & 14 & 2 & 29 \\
\hline Spiti & 615 & 8.1 & 15.5 & 2 & 15.3 & 1 & 50 & - & - & 1 & 50 & 0 & 0 \\
\hline \multicolumn{14}{|c|}{ Sutlej River } \\
\hline at Namgia & 711 & 19.2 & 14.0 & 3 & 32.0 & 2 & 67 & - & - & 0 & 0 & 1 & 33 \\
\hline at Jangi & 286 & 7.8 & 14.5 & 1 & 17.5 & 1 & 100 & - & - & 0 & 0 & 0 & 0 \\
\hline at Karchham & 379 & 11.7 & 15.2 & 3 & 8.6 & 1 & 33 & 1 & 33 & 0 & 0 & 1 & 33 \\
\hline at Wangtoo & 2059 & 14.4 & 15.4 & 8 & 30.1 & 6 & 75 & 1 & 13 & 0 & 0 & 1 & 13 \\
\hline
\end{tabular}

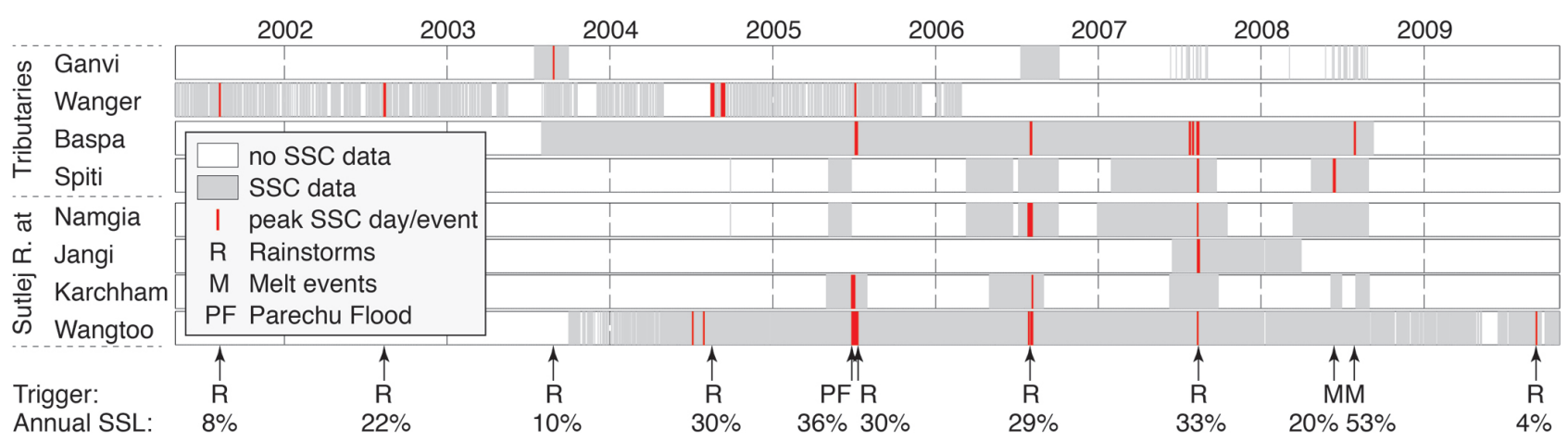

Fig. 4. Time series of peak SSC days/events within the Sutlej catchment. Plausible triggers that are related to peak SSC days/events and catchment-average percentages on the annual suspended sediment load (SSL) are indicated at the bottom. PF (Parechu Flood) is a rain-onsnow event that led to the breach of a landslide dam and caused significant flooding downstream.

stations. Rainstorms associated with peak SSC events typically last for 1-3 days corroborating previous findings (Wulf et al., 2010). Our longest and most complete SSC data sets, covering five to six years, stem from the Wanger and Baspa Rivers and the Sutlej River at Wangtoo, and indicate that 57$80 \%$ of all peak SSC events are directly related to rainstorms (Table 4). Rainstorm-related peak SSC events occur almost on an annual basis in the semi-arid orogenic interior. At the Sutlej River at Wangtoo, these rainstorm-related events account for $\sim 20 \%$ of the total suspended sediment flux.

Whereas peak SSC events are generally associated with the most intense rainstorms between July and August, numerous rainstorms ( $>$ 90th percentile) throughout the monsoon season leave no comparable imprint on the SSC record (Fig. 7).

\subsection{Spatial patterns in suspended sediment yields}

In our study area, the mean SSC decreases downstream along the Sutlej River from the Tibetan Plateau to the Himalayan Crest, followed by an increase towards the Himalayan Front (Fig. 8a). In contrast to the 8-fold decrease in mean annual SSC from the Tibetan Plateau to the Himalayan Crest, runoff increases by a factor of 20 (Table 2) and, therefore, mean annual suspended sediment yields ( $\mathrm{SSY}_{\text {eff }}$ ) (Eq. 1) continuously increase (Fig. 8a). Despite the high SSC levels at the Tibetan Plateau, low runoff in this arid region results in a comparably low $\mathrm{SSY}_{\text {eff }}$ (ca. $250 \mathrm{t} \mathrm{km}^{-2} \mathrm{yr}^{-1}$ ). On the contrary, the Himalayan Crest is characterized by high runoff along with moderate SSC, which results in moderately high levels of mean annual SSY ${ }_{\text {eff }}\left(\right.$ ca. $1000 \mathrm{t} \mathrm{km}^{-2} \mathrm{yr}^{-1}$ ). At the Himalayan Front, sediment concentration and runoff are both

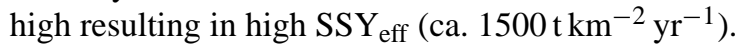




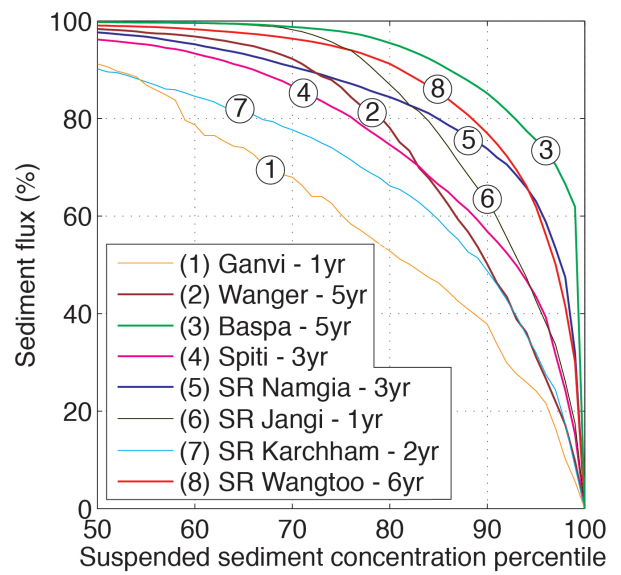

Fig. 5. Percentage of peak SSC events on total suspended sediment flux. Length of the data set is given in the legend. The legend shows tributary stations (1-4) from south to north and the Sutlej River (SR) main stem stations (5-8) in downstream direction (cf. Fig. 1).

\subsection{Seasonal variations of suspended sediment flux}

In all rivers, except for the Ganvi River, we find a weakly pronounced anticlockwise hysteresis loop of mean monthly sediment flux shown in a characteristic example for the Sutlej River at Wangtoo (Fig. 9a). This anticlockwise hysteresis loop is most pronounced in the Wanger River (Fig. 9b) and indicates less suspended sediment transport on the rising limb of the hydrograph (May, June) compared to the falling limb (September, October) for a given discharge. For individual years, we find a pronounced anticlockwise hysteresis loop in the daily sediment flux during 2001, 2002, 2006, and 2007. During these years, the differences between lower SSC in May and June and higher SSC during September and October are most distinctive. For the remaining years, these seasonal differences are less pronounced or do not exist. During July and August, when the monsoonal rainfall and glacial discharge peak in this region, variations in daily SSC and river discharge are very pronounced and no characteristic daily pattern is recognizable. The simplified mean monthly hysteresis loop of individual years, however, is on an annual basis strongly influenced by the timing and magnitude of peak SSC events, which can alter the orientation and shape of the mean monthly hysteresis. We suggest that a mean monthly hysteresis loop based on SSC data sets $\geq 5$ years provides a more accurate representation of the seasonal sediment flux, because it is less affected by infrequent extreme events.

\section{Discussion}

In our study, we observe an overall increase in suspended sediment flux from the Tibetan Plateau to the Himalayan Front. This spatial pattern could reflect either process-based differences, differences in erodibility, or gradients in sediment availability. Large downstream differences in erosion processes are likely between the arid Tibetan Plateau, the snowfall-dominated Himalayan Crest, and the rainfalldominated Himalayan Front. Catchment-wide differences in vegetation cover and rock types also suggest pronounced variations in erosion susceptibility. Furthermore, the supply of sediment that can be mobilized during extreme hydrometeorological events with high runoff contrasts sharply along the Sutlej River. In the following, we discuss variations in sediment availability and sediment supply based on their climatic and geologic controls and compare spatial patterns of sediment flux in the Himalaya.

\subsection{Monsoonal controls on suspended sediment flux}

During our observation period (2001-2009), we identified monsoonal rainstorms ( $>90$ th percentile) as the dominant driving mechanism to deliver sediments to the steams across different climatic zones from the Himalayan Front to the Tibetan Plateau. Previous studies emphasized the high rainstorm magnitudes and frequencies at the Himalayan Front, which contrast the more pronounced rainstorm magnitude variability in the orographically shielded Himalayan Crest and Tibetan Plateau regions (Craddock et al., 2007; Wulf et al., 2010). This observation is supported by our SSC measurements, which indicate frequent, low-magnitude SSC pulses during rainstorms at the Himalayan Front and less frequent but high-magnitude SSC pulses at the Himalayan Crest and Tibetan Plateau region.

During a field visit in September 2009 (cf. Fig. 6a), we witnessed an intense rainstorm event in the semi-arid region leeward of the main orographic barrier, which triggered widespread rockfalls, debris flows, and mudflows. Similar events were previously observed during a prolonged intense rainfall phase at the end of August 2002 (Bookhagen et al., 2005). The correlation between peak SSC events and rainstorms suggests that rainstorms frequently trigger landslides and debris flows and enhance fluvial erosion due to increased river discharge. However, several rainstorms throughout the monsoon season leave no elevated imprint on the SSC record (Fig. 7). This effect may be related to the variations in sediment availability, rainstorm intensity, or soil moisture thresholds as identified in other parts of the Himalaya (e.g. Dahal and Hasegawa, 2008; Gabet, 2004; Soja and Starkel, 2007). Unfortunately, our data do not allow to better constrain the suspended sediment sources. Likewise, the TRMM 3B42based identification of daily rainstorms does not provide more detailed information on their peak or mean rainfall intensities. We observe that some of the rainstorms that follow particularly strong rainstorms within a few weeks result in lower suspended sediment concentrations in the fluvial system; however, this is not a universal relationship. We also rejected our initial assumption that rainstorms during the later monsoon season result in overall lower suspended sediment 

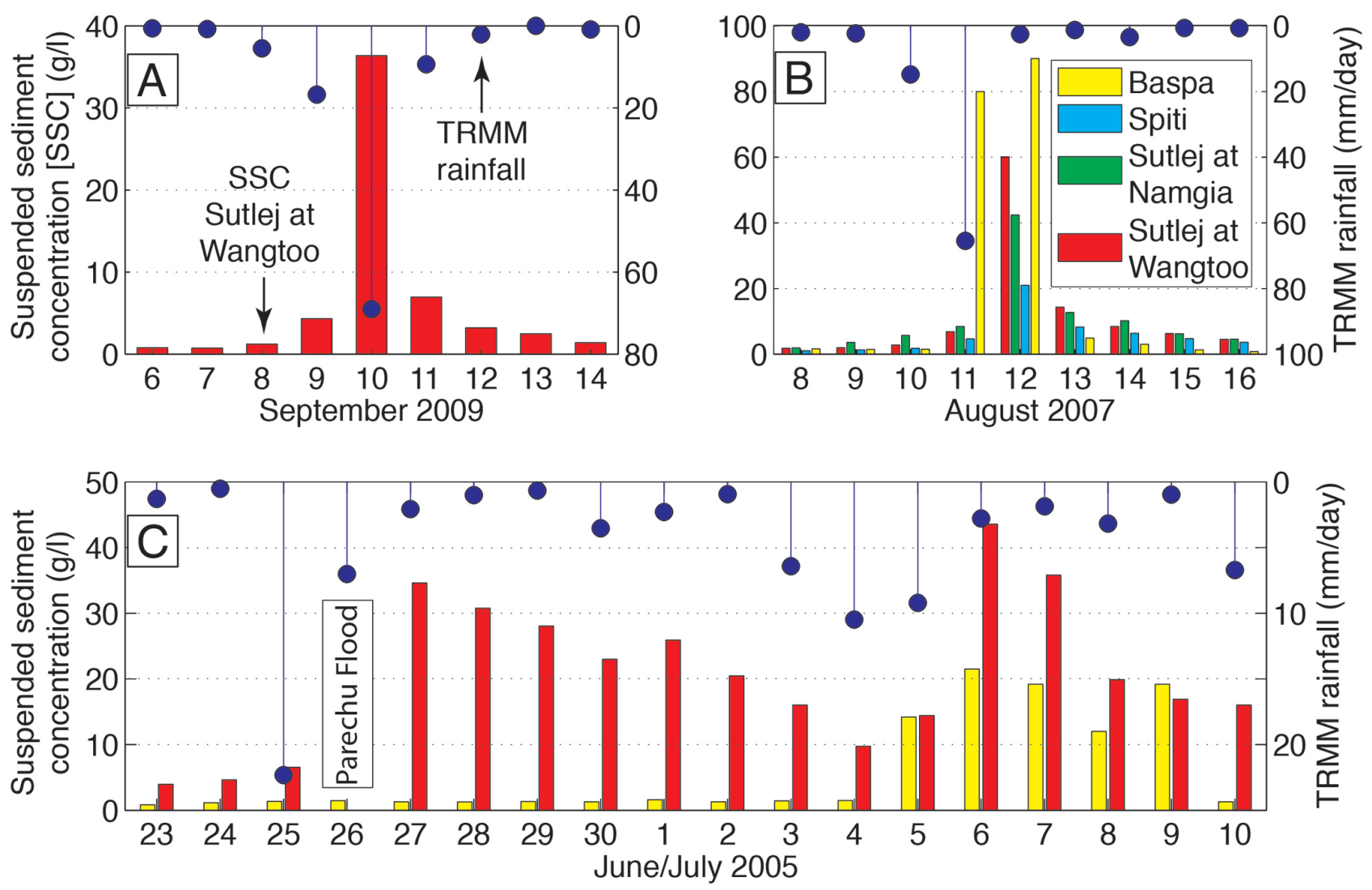

Fig. 6. Relation between peak SSC events and rainfall. (A) Peak SSC event triggered by a 2-day rainstorm (>90th percentile) during September 2009. Daily rainfall amounts are derived from TRMM 3B42 averaged over the Sutlej catchment at Wangtoo. (B) Peak SSC event caused by a synoptic rainstorm affecting several catchments in the Sutlej Valley during August 2007. Larger catchments (e.g. Spiti) show longer response times. Color coding indicates location of SSC measurements. (C) SSC response of the Sutlej River at Wangtoo to the lake outburst flood (Parechu Flood during June/July 2005) and a successive rainstorm, which especially affected SSC levels in the Baspa River.

concentrations. This may be related to snow- and ice melting, which contribute additional suspended sediment during the later monsoon season.

The frequent occurrence of peak SSC events during rainstorms in July and August could also indicate that rainfallinduced runoff in glacial and periglacial areas represents an important sediment source (e.g. Collins and Hasnain, 1995; Haritashya et al., 2006; Singh et al., 2003). This argument is supported by studies of water and sediment discharge from the Gangotri and Dokriani Glacier (cf. Fig. 1a), western Himalaya, which indicate that glacial sediment flux peaks during monsoonal rainstorms (Haritashya et al., 2006; Singh et al., 2003; Thayyen et al., 2007). In addition, we observe the most pronounced anticlockwise SSC-hysteresis loop in the glaciated Wanger catchment, which indicates an increase in SSC during the course of the monsoon season. Because late in the season the snowline is elevated and more glacial and periglacial ground is exposed, we suspect that these areas may act as source regions from where stored sediments are evacuated. Furthermore, the coeval seasonal temperature increase results in a decline in the frozen and permafrost areas.

\subsection{Extreme melt events}

Besides the apparent relation between rainstorms and peak sediment flux, there are few peak SSC events that cannot be related to monsoonal rainfall. Such an event occurred in June 2008 in the Spiti tributary during the absence of major earthquakes (Table A2) or rainstorms (Fig. 10a). Instead, the increase in SSC from early to mid-June corresponds closely to an increase in air temperature. Despite heavy rainfall during mid and late June, the SSC decreased, which again corresponds to decreases in air temperature (Fig. 10a). This correlation suggests that the suspended sediment flux during this event was induced by changes in temperature, which suggests a snow- or glacial-melt-related source for the sediment discharge. During the initiation of this peak SSC event, snow coverage was less than $15 \%$ in the Spiti catchment and decreased moderately during the 12-day peak sediment discharge period from 14.2 to $8.8 \%$ (Fig. 10b) with respect to a minimum snow cover of $1.7 \%$ on 25 July 2005. Therefore, it is unlikely that snow avalanches or snow melt-derived floods mobilized large amounts of sediment. In contrast, 

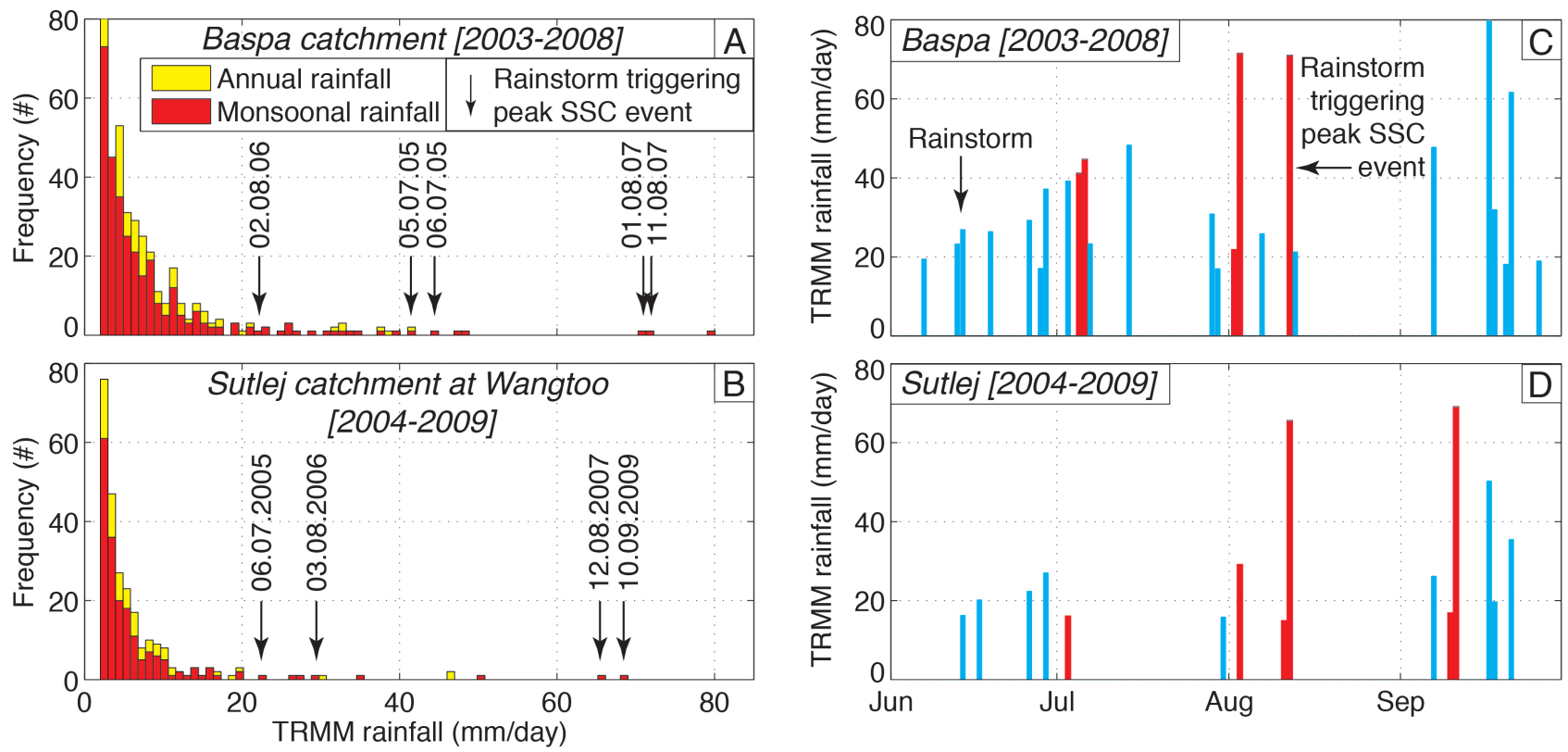

Fig. 7. Histograms of daily TRMM 3B42 data displaying annual and monsoonal (June-September) rainfall during the given time period for the Baspa catchment (A) and the Sutlej catchment at Wangtoo (B). Arrows indicate rainstorms ( $\geq 90$ th rainfall percentile)that are associated with peak SSC days ( $\geq 99$ th SSC percentile). Panel (C) and (D) represent the 6-yr time series of rainstorms and their impact on peak SSC days during the monsoonal period for the Baspa catchment and Sutlej catchment at Wangtoo, respectively.

the onset of this peak SSC events coincides with the initiation of glacial ablation, as indicated by the snowline retreat to glacial elevations. This initiation of glacial runoff generally corresponds to the evacuation of subglacial sediment (e.g. Haritashya et al., 2006). We suggest that sediments mobilized by glacial meltwaters most likely account for this peak SSC event. For the measurement period from 23 April to 29 August 2008, this suspended sediment discharge event (3-29 June) accounted for 58\% of the total 3-yr suspended sediment flux, corresponding to $3.1 \mathrm{Mt}$ of suspended sediment load or $137.3 \mathrm{t} \mathrm{km}^{-2}$ day $^{-1}$ (accounting for the glacial area only).

\subsection{The 26 June 2005: Parechu flood}

Floods efficiently erode and transport sediment stored in the riverbed (Baker and Kale, 1998; Bookhagen et al., 2005; Coppus and Imeson, 2002; Hartshorn et al., 2002). On 26 June 2005, a flood occurred in the Parechu River, a main tributary of the Spiti River, which was caused by the failure of a landslide dam that blocked the river (cf. Fig. 1a). This landslide occurred in late spring/early summer of 2004 and formed an artificial lake, which covered an area of $1.9 \mathrm{~km}^{2}$ with a maximum depth of about $40 \mathrm{~m}$ storing about $64 \times 10^{6} \mathrm{~m}^{3}$ of water in September 2004 (Gupta and Sah, 2007). The dam failure released a flood wave of about $20 \mathrm{~m}$ in height with a maximum discharge of about $2000 \mathrm{~m}^{3} \mathrm{~s}^{-1}$ estimated at the confluence with the Sutlej (Gupta and Sah, 2007). The 4-yr averaged discharge at this site is $100 \mathrm{~m}^{3} \mathrm{~s}^{-1}$.
Further downstream, the peak SSC of the Sutlej River at Wangtoo was measured to be $151 \mathrm{gl}^{-1}$ (SJVNL, 2005) with an estimated peak discharge of $4000 \mathrm{~m}^{3} \mathrm{~s}^{-1}$ (Kumar et al., 2007). The day preceding the flood, TRMM indicates heavy rainfall of $10-20 \mathrm{~mm} \mathrm{day}^{-1}$ in semi-arid areas upstream of the landslide, which coincides with pronounced snow melt as indicated by MODIS imagery between 23 and 27 June 2005 . During the 5-day period, snow cover in the upstream area $\left(5294 \mathrm{~km}^{2}\right)$ reduced by $52.3 \%$ from $830.1 \mathrm{~km}^{2}(15.7 \%)$ to $395.8 \mathrm{~km}^{2}(7.5 \%)$ with respect to a minimum snow cover of $32.5 \mathrm{~km}^{2}(0.6 \%)$ on 14 August 2005 . Therefore, it is likely that the dam failure was triggered by a combination of rainfall and rain-on-snow event, which caused an increase in river discharge and hydrostatic pressure on the dam.

We estimate the suspended sediment load of the flood event (26 June-3 July 2005) at the Sutlej River at Wangtoo to be about $34 \mathrm{Mt}$, which equates to $88 \mathrm{t} \mathrm{km}^{-2} \mathrm{day}^{-1}$ or $41 \%$ of the 2005 annual suspended sediment budget. This conservative estimate is based on an average daily discharge of $2000 \mathrm{~m}^{3} \mathrm{~s}^{-1}$ and a SSC of $50 \mathrm{gl}^{-1}$ for the flood day, for which only limited measurements are available (Fig. 6c). The estimated SSC of average daily of $50 \mathrm{~g}^{-1}$ is constrained by a maximum SSC of $151 \mathrm{gl}^{-1}$ on 26 June and a minimum SSC of $32 \mathrm{~g} \mathrm{l}^{-1}$ on 27 June. The decrease in SSC during the 8-day period after the flooding day was rather linear as compared to the exponential decrease during rainstorms (Fig. 6), which might be caused by the exceptionally high river discharge $\left(\sim 1700 \mathrm{~m}^{3} \mathrm{~s}^{-1}\right)$ until 30 June 2005 . Compared to the total eight peak SSC events measured at the Sutlej River at 


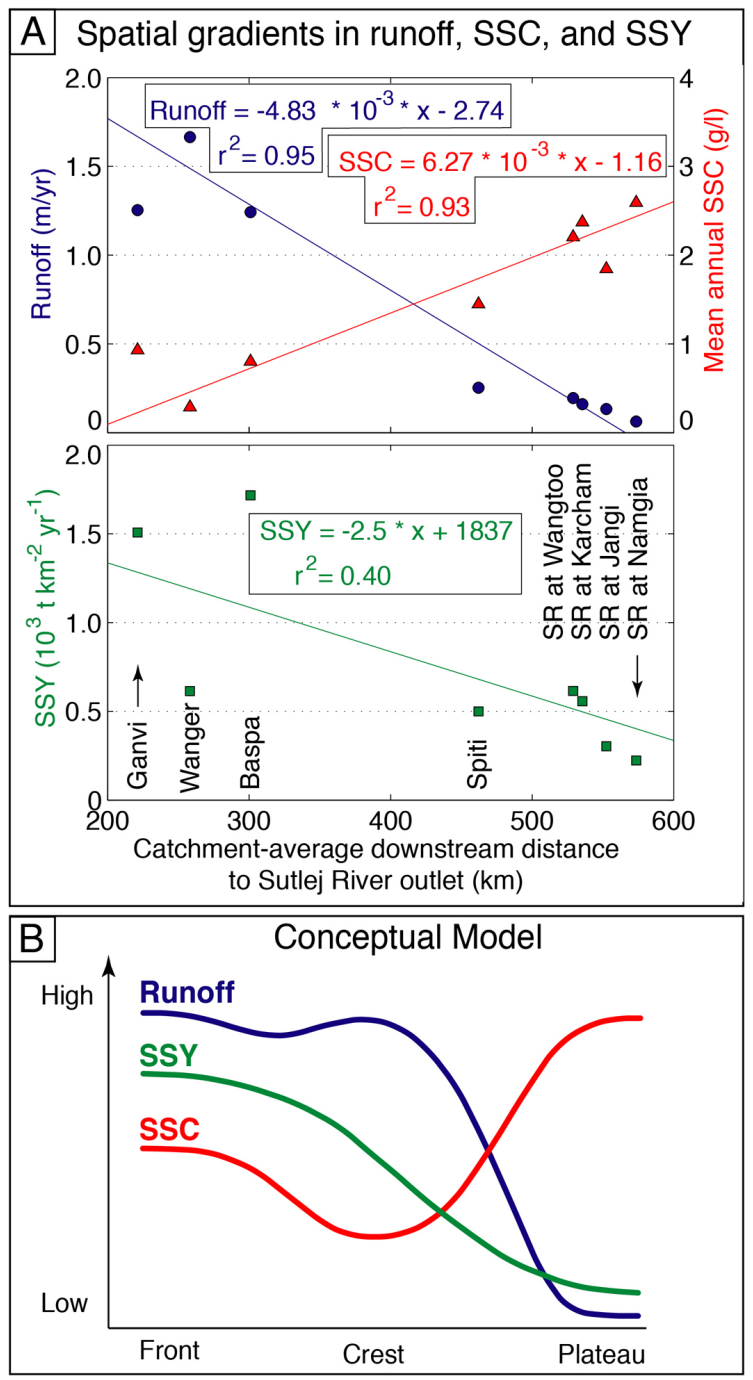

Fig. 8. (A) Spatial gradients in runoff, suspended sediment concentration (SSC), and effective suspended sediment yield (SSY $\mathrm{eff}_{\text {, }}$ based on the summer half-year only) for the Sutlej River and tributary catchments. Correlations are weighted by the number of measurement years. The correlation is based on the catchment-average downstream distance to the Sutlej River outlet to account for the predominant catchment area location. (B) Conceptual model of the spatial distribution of SSC, runoff, and SSY from the Tibetan Plateau to the Himalayan Crest and the Himalayan Front.

Wangtoo during 2004-2009, the Parechu flood accounted for $51 \%$ of the total suspended sediment load transported during these peak SSC events. Overall, the 8-day flood accounted for $18.3 \%$ of the total SSL during the 6-yr measurement period (2004-2009) of the Sutlej River at Wangtoo. Due to its prolonged duration ( 8 days), it was almost three times the magnitude of the highest rainfall-induced peak SSC event (5 day duration) in the same year (Fig. 6c). Therefore, the Parechu flood can be considered as the dominant erosional event during our observation period (2001-2009).

\subsection{Geologic controls on suspended sediment flux}

The supply of sediment that can be mobilized during hydrometeorological extreme events with high runoff contrasts sharply along the Sutlej River. In the Tibetan Plateau region, many hillslopes feature large alluvial fans at their base, which provide abundant sediments that can be easily mobilized by increased river discharge or rainstorms (Fig. 11a). We argue that glacial and periglacial processes are highly efficient at eroding the layered and densely fractured metasedimentary rocks (Heimsath and McGlynn, 2008; Molnar et al., 2007). The decrease in mean annual SSC from the Tibetan Plateau towards the Himalayan Crest is primarily caused by an increase in runoff through snow and glacial melt, which dilutes the suspended sediment concentration. This increase in runoff results in an increase in transport capacity, which also includes a higher bedload fraction (e.g. Pratt-Sitaula et al., 2007). In contrast to the bare Himalayan Crest and Tibetan Plateau, the Himalayan Front is characterized by lush vegetation, which indicates highly developed soils. Despite the protective vegetation cover, these soils are commonly detached by rain splash, surface runoff, creep, bioturbation, and shallow landsliding (Burbank, 2009; Morgan, 2004). In addition, large fluvial terraces and alluvial fans characterize the lower-elevation Sutlej River and tributaries (Bookhagen et al., 2006), because wider river valleys and lower river gradients allow larger storage volumes for sediments, which can be reworked during higher discharges (Fig. 11c). Because of this high sediment availability, which is mobilized by pronounced orographic rainfall, increased SSC characterizes the rivers of the Himalayan Front.

Our earthquake record analysis in conjunction with peak SSC events suggests that low- and intermediate-magnitude earthquakes $\left(M_{\mathrm{S}}<6\right)$ have a low impact on the suspended sediment flux. During our measurement period (2001-2009), no earthquake was related to a peak SSC event. In the event of the $6.4\left(M_{\mathrm{S}}\right)$ earthquake during 1999 in Garhwal Himalaya, Barnard et al. (2001) found that only one-third of all 338 reactivated and induced landslides reached the rivers. However, stronger earthquakes with magnitudes $M_{\mathrm{S}}<7$ might yield an even more pronounced effect on the overall sediment flux (Hovius et al., 2011). Despite several studies elaborating the link between earthquakes, landslides, and fluvial sediment transport in seismically active mountain belts (e.g. Dadson et al., 2003; Meunier et al., 2008), we could not detect significant increases of suspended sediment concentrations related to earthquake activity in Sutlej catchment during the study period (2001-2009). We argue that the strong climatic seasonality, climatic gradient, and large catchment sizes dominate sediment transport in the Himalaya. In contrast to other tectonically active mountain belts (e.g. New Zealand, Taiwan), the Tibetan part of the Himalayan mountain belt is characterized by large, presently dry areas and exceptionally wide river valleys, which serve 

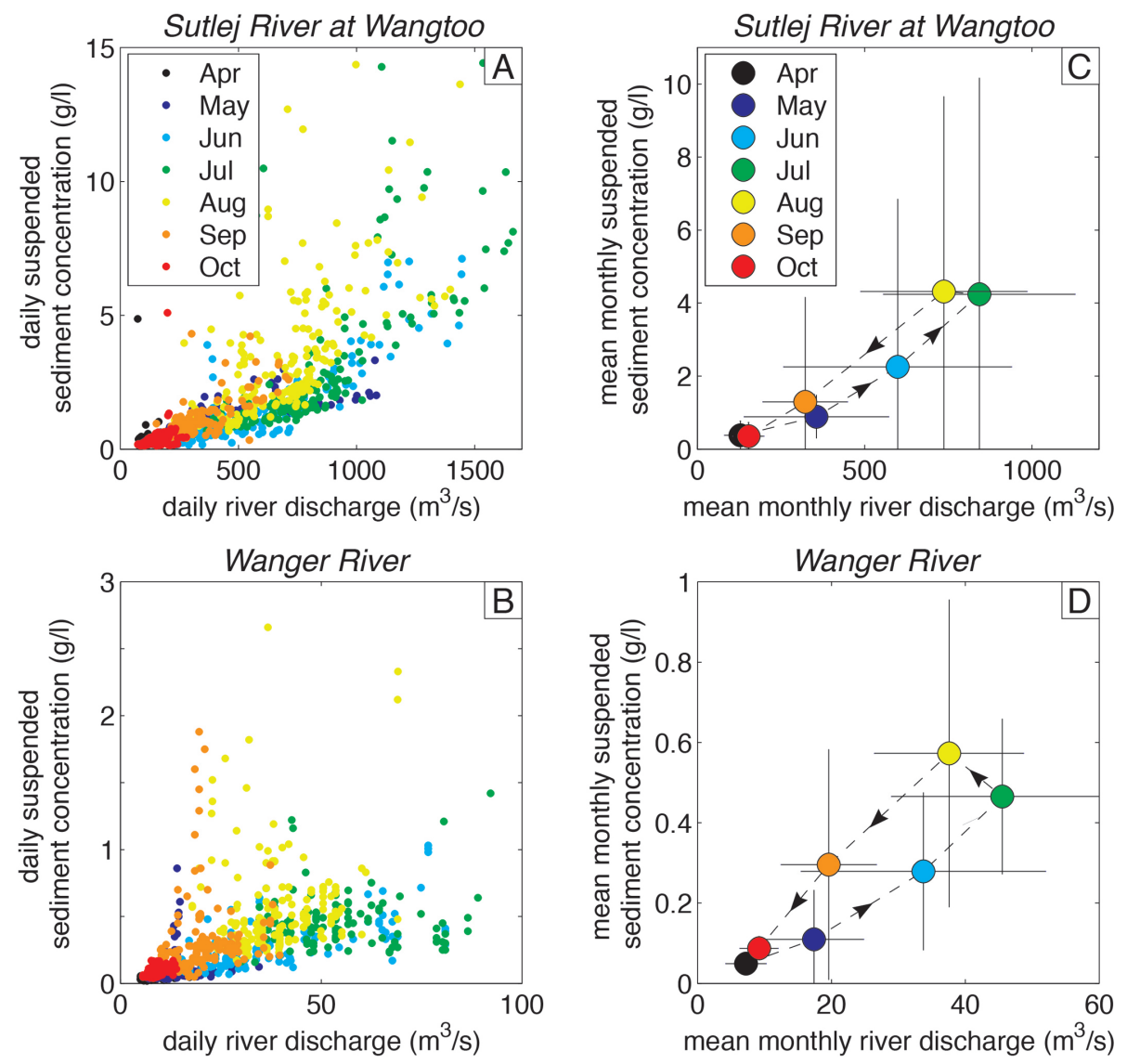

Fig. 9. Time series of daily river discharge and suspended sediment concentration data separated by month of the Sutlej River at Wangtoo (A) and the Wanger River (B) covering five and six years, respectively. Hysteresis loops of the mean monthly suspended sediment flux in the Sutlej River at Wangtoo $(\mathbf{C})$ and the Wanger River (D). The error bars represent the daily standard deviation $( \pm 1 \sigma)$ of the monthly river discharge and SSC mean, respectively.

as transient sediment buffers that may temporally store or increase in sediment flux.

\subsection{Spatial patterns in modern Himalayan erosion}

In a last step, we attempt to place our results in the context of Himalaya-wide suspended sediment flux measurements. Despite difficulties in comparing different time spans of SSY, the long-term ( $>5 \mathrm{yr}$ ) mean of the SSY in Himalayan rivers indicates some first-order spatial patterns.

In general, the elevated, arid regions are characterized by low sediment yields, due to their low runoff. This pattern is evident in the upstream catchments of the Indus, Chenab, Sutlej and Marsyandi Rivers (Table 5). In a downstream direction, the sediment yield of these rivers increases gradually with runoff due to the high sediment flux of tributaries with higher rainfall-triggered hillslope erosion and a high glacial density, indicating high snowfall magnitudes and sporadic, intense monsoonal rainfall events. Consequently, the general north-to-south increase in Himalayan precipitation and runoff is also reflected in the sediment flux (Fig. 12).
Sediment flux measurements in proglacial streams exhibit large variations in their suspended sediment yields (Table 6), which might be related to differences in lithologies, topography, glacial debris cover, and seasonal precipitation (Scherler et al., 2011a,b). Whereas some glaciers in the western Karakorum and western Himalaya are characterized by peak suspended sediment yields exceeding those in monsoonal regions, others in the eastern Karakorum or central Himalaya exhibit low sediment yields and are comparable to sediment yields from the arid Tibetan Plateau (Fig. 12). Consequently, the glacial sediment yield exerts a large influence on the sediment flux characteristics of their downstream rivers. This is exemplified by the high sediment yield of the Hunza River $\left(3373 \mathrm{t} \mathrm{km}^{-2} \mathrm{yr}^{-1}\right)$ that is fed by the Batura glacier $\left(6086 \mathrm{t} \mathrm{km}^{-2} \mathrm{yr}^{-1}\right)$, which contrasts the relatively low sediment yield of the Shyok River $\left(924 \mathrm{t} \mathrm{km}^{-2} \mathrm{yr}^{-1}\right)$ that is fed by the Siachen glacier $\left(707 \mathrm{t} \mathrm{km}^{-2} \mathrm{yr}^{-1}\right.$ ) (Tables 4 and 5). 
Table 5. Compilation of suspended sediment flux data for some Himalayan rivers. We first list tributaries followed by their corresponding main stems in downstream direction ranging from west to east. The catchment denudation rate is based on a bulk rock density of $2.65 \mathrm{~g} \mathrm{~cm}{ }^{-3}$ and accounts only for the suspended sediment flux. Note that data from this study reflect sediment flux during the summer half-year only.

\begin{tabular}{|c|c|c|c|c|c|c|c|c|c|c|c|}
\hline \multirow[t]{2}{*}{ River } & \multirow{2}{*}{$\begin{array}{l}\text { Location } \\
\text { [Ref. to Fig. } \\
12]\end{array}$} & \multirow{2}{*}{$\begin{array}{c}\text { Lati- } \\
\text { tude } \\
\left.{ }^{\circ}\right]\end{array}$} & \multirow{2}{*}{$\begin{array}{l}\text { Longi- } \\
\text { tude } \\
\left.{ }^{\circ}\right]\end{array}$} & \multirow{2}{*}{$\begin{array}{r}\text { Ele- } \\
\text { vation } \\
{[\mathrm{m}]}\end{array}$} & \multirow{2}{*}{$\begin{array}{r}\text { Drainage } \\
\text { area } \\
{\left[\mathrm{km}^{2}\right]}\end{array}$} & \multirow{2}{*}{$\begin{array}{l}\text { Obs. } \\
\text { period }\end{array}$} & \multirow{2}{*}{$\begin{array}{l}\text { Runoff } \\
{\left[\mathrm{m} \mathrm{yr}^{-1}\right]}\end{array}$} & \multicolumn{2}{|c|}{ Suspended-Sediment } & \multirow{2}{*}{$\begin{array}{l}\text { Catchment } \\
\text { denudation } \\
{\left[\mathrm{mm} \mathrm{yr}^{-1}\right]}\end{array}$} & \multirow[t]{2}{*}{ Reference } \\
\hline & & & & & & & & $\begin{array}{r}\text { Load } \\
{\left[10^{6} \mathrm{tyr}^{-1}\right]}\end{array}$ & $\begin{array}{r}\text { Yield } \\
{\left[\mathrm{t} \mathrm{km}^{-2} \mathrm{yr}^{-1}\right]}\end{array}$ & & \\
\hline Shyok & Yugo & 35.18 & 76.10 & 2469 & 33670 & 1973-1998 & 0.33 & 31.1 & 924 & 0.35 & Ali and De Boer (2007) \\
\hline Shigar & Shigar & 35.33 & 75.75 & 2438 & 6610 & $1985-1998$ & 0.99 & 16.8 & 2542 & 0.96 & \\
\hline Hunza & Dainyor Bridge & 35.93 & 74.38 & 1370 & 13157 & $1966-1998$ & 0.80 & 44.4 & 3373 & 1.27 & \\
\hline Gilgit & Gilgit [1] & 35.93 & 74.31 & 1430 & 12095 & $1963-1998$ & 0.74 & 6.0 & 498 & 0.19 & \\
\hline Gilgit & Alam Bridge & 35.77 & 74.60 & 1280 & 26159 & $1966-1998$ & 0.78 & 54.8 & 2095 & 0.79 & \\
\hline Astore & Doyian & 35.55 & 74.70 & 1583 & 4040 & $1974-1998$ & 1.01 & 1.7 & 427 & 0.16 & \\
\hline Gorband & Karora [1] & 34.89 & 72.77 & 880 & 635 & $1975-1997$ & 1.04 & 0.2 & 250 & 0.09 & \\
\hline Brandu & Daggar & 34.50 & 72.46 & 700 & 598 & $1970-1998$ & 0.30 & 0.3 & 442 & 0.17 & \\
\hline Siran & Phulra & 34.31 & 73.08 & 732 & 1057 & $1970-1998$ & 0.63 & 2.4 & 2306 & 0.87 & \\
\hline Siran & Thapla & 34.13 & 72.90 & 440 & 2799 & $1960-1973$ & 0.35 & 2.9 & 1024 & 0.39 & \\
\hline Indus & Kharmong [1] & 34.93 & 76.22 & 2542 & 67856 & $1983-1998$ & 0.23 & 23.9 & 355 & 0.13 & \\
\hline Indus & Kachura & 35.45 & 75.42 & 2341 & 112665 & $1970-1998$ & 0.30 & 80.1 & 710 & 0.27 & \\
\hline Indus & Partab Bridge & 35.73 & 74.62 & 1250 & 142825 & 1963-1995 & 0.39 & 138.3 & 968 & 0.37 & \\
\hline Indus & Shatial Bridge & 35.53 & 73.56 & 1040 & 150220 & 1983-1998 & 0.42 & 118.6 & 789 & 0.30 & \\
\hline Indus & Barsin & 35.30 & 73.27 & 780 & 157600 & $1974-1979$ & 0.36 & 140.5 & 892 & 0.34 & \\
\hline Indus & Besham Qila & 34.92 & 72.88 & 580 & 162393 & 1969-1998 & 0.47 & 194.4 & 1197 & 0.45 & \\
\hline Indus & Darband [1] & 34.36 & 72.84 & 440 & 166154 & $1960-1973$ & 0.47 & 287.6 & 1731 & 0.65 & \\
\hline Chandra & Ghousal & 32.53 & 76.96 & 2850 & 2490 & $1978-1995$ & - & 1.3 & 513 & 0.19 & Rao et al. (1997) \\
\hline Bhaga & Tandi [2] & 32.54 & 76,98 & 2846 & 1530 & $1977-1995$ & - & 0.6 & 371 & 0.14 & \\
\hline Marusudar & Tillar [2] & 33.57 & 75.79 & 2066 & 2800 & $1968-1987$ & - & 1.0 & 373 & 0.14 & \\
\hline Marusudar & Sirshi & 33.46 & 75.86 & 1620 & 3335 & $1968-1995$ & - & 3.1 & 939 & 0.35 & \\
\hline Marusudar & Kuriya & 33.35 & 75.73 & 1106 & 3960 & 1968-1989 & - & 3.5 & 878 & 0.33 & \\
\hline Chenab & Benzwar & 33.36 & 75.74 & 1135 & 10040 & $1972-1995$ & - & 16.0 & 1597 & 0.60 & \\
\hline Chenab & Premnagar & 33.15 & 75.70 & 886 & 15490 & $1968-1995$ & - & 21.1 & 1363 & 0.51 & \\
\hline Chenab & Dhamkund & 33.24 & 75.14 & 600 & 18750 & $1968-1995$ & - & 35.6 & 1900 & 0.72 & \\
\hline Chenab & Akhnoor [2] & 32.89 & 74.74 & 305 & 21808 & $1971-1995$ & - & 22.4 & 1029 & 0.39 & \\
\hline Spiti & Khab & 31.81 & 78.64 & 2550 & 12477 & $2005-2008$ & 0.26 & 6.2 & 499 & 0.19 & this study \\
\hline Baspa & Sangla & 31.42 & 78.26 & 2550 & 989 & $2004-2008$ & 1.14 & 1.7 & 1717 & 0.65 & \\
\hline Wanger & Kafnu & 31.62 & 78.02 & 2450 & 310 & $1999-1905$ & 1.72 & 0.2 & 614 & 0.23 & \\
\hline Ganvi & Ganvi & 31.56 & 77.75 & 1730 & 117 & 2003 & 1.27 & 0.2 & 1507 & 0.57 & \\
\hline Sutlej & Khab [3] & 31.80 & 78.64 & 2550 & 30950 & $2005-2008$ & 0.07 & 6.9 & 223 & 0.08 & \\
\hline Sutlej & Jangi & 31.63 & 78.43 & 2310 & 44732 & 2007 & 0.15 & 13.5 & 302 & 0.11 & \\
\hline Sutlej & Karchham & 31.50 & 78.19 & 1820 & 46438 & $2006-2007$ & 0.16 & 25.8 & 556 & 0.21 & \\
\hline Sutlej & Wangtoo & 31.56 & 77.98 & 1480 & 48316 & 2004-2009 & 0.20 & 29.7 & 615 & 0.23 & \\
\hline Sutlej & Suni & 31.24 & 77.12 & 645 & 52983 & 1994-1996 & - & 36.9 & 686 & 0.26 & Jain et al. (2003) \\
\hline Sutlej & Kasol [3] & 31.38 & 76.88 & 520 & 53768 & 1994-1996 & - & 43.2 & 816 & 0.31 & \\
\hline Yamuna & Tajewala [4] & 30.32 & 77.58 & 370 & 9572 & 1983 & 1.10 & 18.1 & 1889 & 0.71 & Jha et al. (1988) \\
\hline Bhagirathi & Maneri & 30.74 & 78.54 & 1295 & 4024 & 2004 & 1.22 & 3.7 & 917 & 0.35 & Chakrapani and Saini (2009) \\
\hline Alaknanda & Srinagar & 30.23 & 78.77 & 524 & 10237 & 2004 & 1.70 & 10.2 & 995 & 0.38 & \\
\hline Ganga & Rishikesh [5] & 30.07 & 78.29 & 330 & 20600 & 2004 & 1.15 & 12.9 & 628 & 0.24 & \\
\hline Dudh Khola & Dudh & 28.52 & 84.36 & 2000 & 491 & $2001-2004$ & 0.67 & 0.2 & 508 & 0.19 & Gabet et al. (2008) \\
\hline Khudi Khola & Khudi & 28.28 & 84.35 & 820 & 152 & $2000-2005$ & 3.54 & 0.5 & 3392 & 1.28 & \\
\hline Marsyandi & Koto & 28.55 & 84.25 & 2640 & 812 & 2001-2004 & 0.76 & 1.4 & 1696 & 0.64 & \\
\hline Marsyandi & Nar [6] & 28.55 & 84.26 & 2650 & 1052 & $2001-2003$ & 0.15 & 0.2 & 170 & 0.06 & \\
\hline Marsyandi & Upper Dharapani & 28.53 & 84.35 & 2030 & 1946 & $2001-2003$ & 0.56 & 1.3 & 678 & 0.26 & \\
\hline Marsyandi & Lower Dharapani & 28.51 & 84.36 & 1880 & 2605 & $2001-2002$ & 0.44 & 2.2 & 848 & 0.32 & \\
\hline Marsyandi & Bhulbule & 28.28 & 84.36 & 788 & 3217 & $2001-2003$ & 0.76 & 2.7 & 848 & 0.32 & \\
\hline Gandak & Triveni [6] & 27.43 & 83.90 & 110 & 37845 & 1980-1989 & 1.53 & 78.5 & 2074 & 0.78 & Sinha and Friend (1994) \\
\hline Brahmaputra & Pasighat [7] & 28.08 & 95.34 & 150 & 249000 & - & 0.80 & 210.0 & 843 & 0.32 & Stewart et al. (2008) \\
\hline
\end{tabular}


Table 6. Suspended sediment flux in proglacial streams of the Himalaya and Karakorum. The catchment denudation rate is based on a bulk rock density of $2.65 \mathrm{~g} \mathrm{~cm}^{-3}$, accounts only for the suspended sediment flux, and relies on the catchment area. Note that the glacial area is always smaller than the catchment area (not shown).

\begin{tabular}{|c|c|c|c|c|c|c|c|c|c|c|c|}
\hline \multirow{2}{*}{$\begin{array}{l}\text { Glacier } \\
\text { [Ref. to Fig. } \\
12]\end{array}$} & \multirow[t]{2}{*}{ River } & \multirow{2}{*}{$\begin{array}{l}\text { Lati- } \\
\text { tude } \\
{\left[{ }^{\circ}\right]}\end{array}$} & \multirow{2}{*}{$\begin{array}{c}\text { Longi- } \\
\text { tude } \\
{\left[{ }^{\circ}\right]}\end{array}$} & \multirow{2}{*}{$\begin{array}{c}\text { Ele- } \\
\text { vation } \\
{[\mathrm{m}]}\end{array}$} & \multirow{2}{*}{$\begin{array}{r}\text { Glacial } \\
\text { area } \\
{\left[\mathrm{km}^{2}\right]}\end{array}$} & \multirow{2}{*}{$\begin{array}{l}\text { Obs. } \\
\text { period }\end{array}$} & \multirow{2}{*}{$\begin{array}{l}\text { Runoff } \\
{\left[\mathrm{m} \mathrm{yr}^{-1}\right]}\end{array}$} & \multicolumn{2}{|c|}{ Suspended-Sediment } & \multirow{2}{*}{$\begin{array}{l}\text { Catchment } \\
\text { denudation } \\
{\left[\mathrm{mm} \mathrm{yr}^{-1}\right]}\end{array}$} & \multirow[t]{2}{*}{ Reference } \\
\hline & & & & & & & & $\begin{array}{l}\text { Load } \\
{\left[10^{6} \mathrm{tyr}^{-1}\right]}\end{array}$ & $\begin{array}{l}\text { Yield } \\
{\left[\mathrm{t} \mathrm{km}^{-2} \mathrm{yr}^{-1}\right]}\end{array}$ & & \\
\hline Siachen $[\mathrm{A}]$ & Nubra & 35.11 & 77.23 & 3570 & 620.0 & $1987-1991$ & 1.36 & 1.26 & 707 & 0.27 & Bhutiyani (2000) \\
\hline Batura $[\mathrm{B}]$ & Hunza & 36.49 & 74.89 & 2530 & 389.4 & 1990 & 1.93 & 3.95 & 6086 & 2.30 & Collins (1995) \\
\hline Raikot [C] & Astore & 35.38 & 74.59 & 3010 & 56.0 & 1986 & 1.01 & $0.32-0.49$ & $3500-5250$ & $1.3-2.0$ & Gardner and Jones (2002) \\
\hline Gangotri [D] & Bhagirathi & 30.95 & 79.04 & 3830 & 286.0 & $2000-2003$ & 0.99 & 2.69 & 4834 & 1.82 & Haritashya et al. (2006) \\
\hline Dokriani $[\mathrm{E}]$ & Bhagirathi & 30.86 & 78.78 & 3710 & 9.7 & 1995-1998 & 1.60 & 0.04 & 2700 & 1.02 & Singh et al. (2003) \\
\hline Langtang $[\mathrm{F}]$ & Trisuli & 28.23 & 85.69 & 4324 & 127.2 & $1985-1986$ & 1.35 & 0.08 & 245 & 0.09 & Ohta et al. (1987) \\
\hline Changme [G] & Tista & 27.91 & 88.70 & 4650 & 4.5 & - & - & 0.003 & 668 & 0.25 & Puri (1999) \\
\hline
\end{tabular}

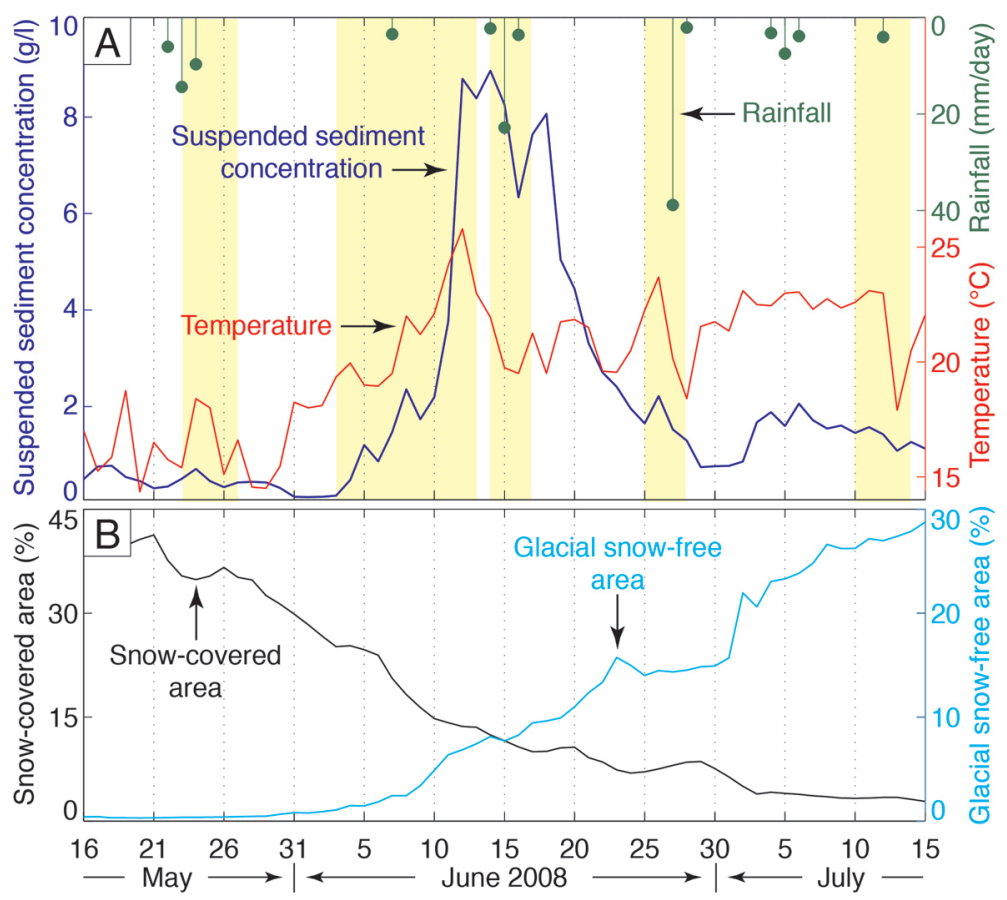

Fig. 10. (A) Comparison of SSC in the Spiti River with TRMM $3 B 42$ rainfall averaged over the Spiti catchment and mean daily air temperature data from Namgia (cf. Fig. 1a) during a 2-month period in mid-2008. Yellow background indicates periods of positive correlation $\left(r^{2}=0.68\right)$ between SSC and temperature variations. (B) Percentage of snow-covered area and the percentage of glacial snow-free area in the Spiti catchment for the same period.

\section{Conclusions}

In this study, we provide a comprehensive analysis of spatiotemporal patterns in suspended sediment flux of the Sutlej River Valley in the western Himalaya. Our analysis is based on gauge measurements of river discharge and suspended sediment concentrations (SCC) of eight catchments in the Sutlej River Valley. Moreover, we combine these data with remotely sensed rainfall and snow-cover data to elucidate driving mechanisms for peak SSC ( $\geq 99$ th percentile) days and assess their impact on the suspended sediment budget. We also discuss the spatiotemporal sediment flux pattern in the context of climatic and geologic controls on sediment availability and supply. Our data reveal the following three key conclusions:

1. Peak erosional events (uppermost $1 \%$ of the SSC data set) account for $\sim 30 \%$ of the suspended sediment flux from the Himalayan Crest and Tibetan Plateau region. These peak SSC events coincide frequently $(57-80 \%)$ with rainstorms, which trigger rockfalls, debris flows, and other mass movements especially in the semi-arid to arid interior of the orogen. Further triggers of peak SSC events are related to extreme melt events and a large lake outburst flood. For example, the Parechu flood in June 2005 was the dominant erosional event (35 MtSSL) and accounted for $41 \%$ of the seasonal 


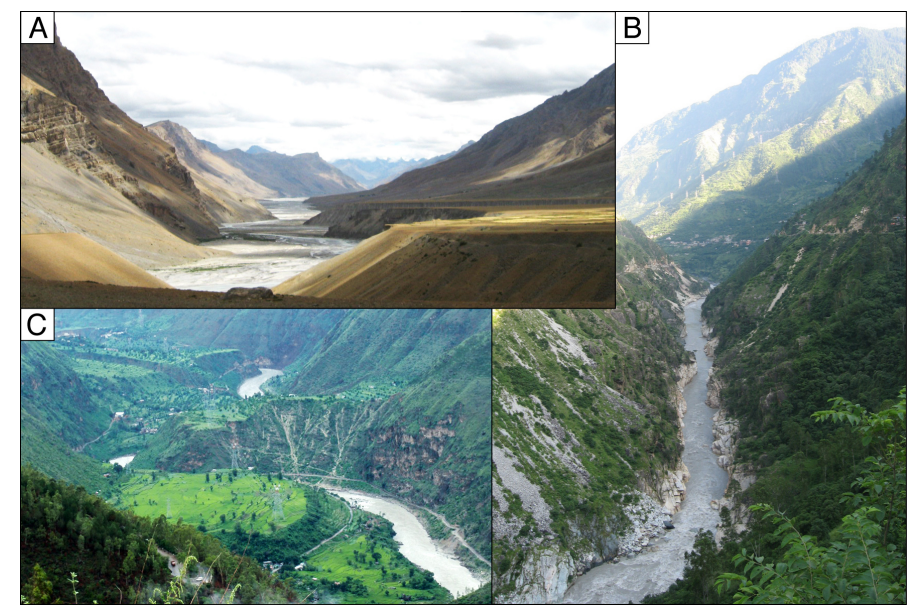

Fig. 11. Images of varying sediment storage in the Sutlej River Valley. (A) Fluvial terrace and alluvial fans along the high-elevated Spiti River, a major tributary to the Sutlej. (B) Incised bedrock along the steep middle Sutlej River section upstream of Rampur (cf. Fig. 1b) at the Himalayan Crest. (C) Extensive fluvial terraces along the moderately inclined lower Sutlej River section downstream of Rampur at the main Himalayan Front (cf. Bookhagen et al., 2006).

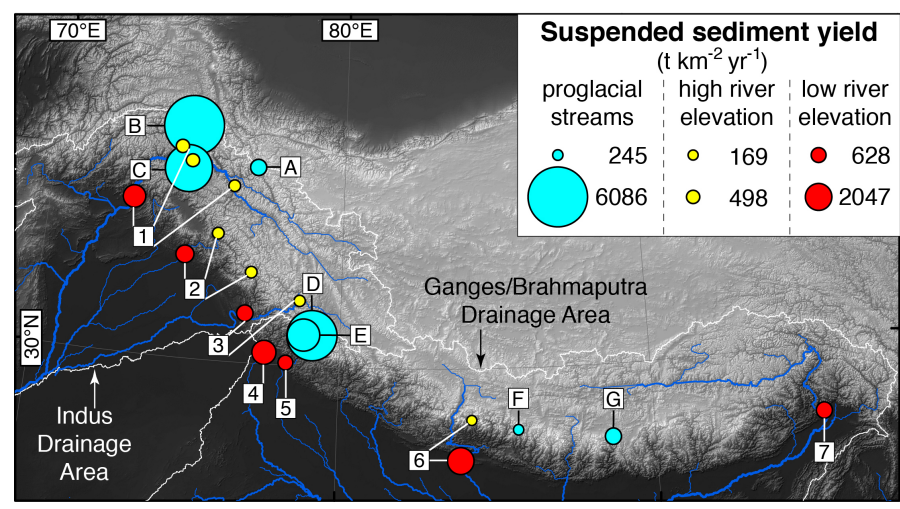

Fig. 12. Compilation of mean annual suspended sediment yield measurements in proglacial streams ( $>2500 \mathrm{~m}$ a.s.1.), upstream river catchments (> $2000 \mathrm{~m}$ a.s.1.), and at outlet locations of major rivers (100-600 ma.s.1.). Letters (A-G) and numbers (1-7) refer to respective references given in Tables 4 and 5. Note the high suspended sediment yield contribution of proglacial streams.

suspended sediment flux. The remote-sensing data preceding the flood document significant rainfall and snow melt, exacerbating the hydrologic pressure on the dam.

2. We observe an increase of suspended sediment flux from the Tibetan Plateau downstream to the Himalayan Front. From north to south along this profile, runoff increases 20-fold, SCC decreases 8-fold from the arid Tibetan Plateau to the Himalayan Crest and increases 3fold southward to the humid, frontal regions. This sediment flux gradient suggests that the magnitude of modern erosion in the western Himalaya is most pronounced at frontal regions, which are characterized by intense monsoonal rainfall and highly developed soils. However, in the semi-arid to arid interior regions, we observe the highest sediment-transport variability with a larger number of extreme events.
3. In all but one catchment, we find an anticlockwise hysteresis loop, which indicates more suspended sediment transport during late summer than during the onset of the monsoonal season. We suggest that seasonal increases in temperature and their impact on permafrost regions and glacial discharge, which peaks in August, play a vital role in mobilizing transiently stored material. Transient sediments are stored in wide river valleys at the Himalayan Front and in the arid Tibetan Plateau region, whereas little sediment is stored in the steep river sections of the Himalayan Crest. In future climate change scenarios, including continuous glacial retreat, permafrost degradation, and more frequent monsoonal rainstorms across the Himalaya, we expect an increase in peak SSC events, which will decrease the water quality in the far downstream reaches, impacting agriculture, drinking-water and hydropower generation. 
Table A1. Overview of annual effective runoff, suspended sediment concentration (SSC), effective suspended sediment load (SSL fff $_{\text {) and }}$ effective suspended sediment yield ( $\mathrm{SSY}_{\mathrm{eff}}$ ) during the summer half-year (May to October) for the Sutlej River and its tributaries gauging stations. Bold number indicate years accounted for to calculate the respective gauging station mean.

\begin{tabular}{|c|c|c|c|c|c|c|c|c|}
\hline \multirow[t]{2}{*}{ Year } & \multicolumn{4}{|c|}{ Tributaries } & \multicolumn{4}{|c|}{ Sutlej River at } \\
\hline & Ganvi & Wanger & Baspa & Spiti & Khab & Jangi & Karchham & Wangtoo \\
\hline \multicolumn{9}{|c|}{ River discharge measurement days during summer (May to October) (\#) } \\
\hline 2001 & 125 & 184 & 0 & 0 & 0 & 0 & 155 & 0 \\
\hline 2002 & 184 & 184 & 0 & 0 & 0 & 0 & 155 & 0 \\
\hline 2003 & 181 & 184 & 143 & 0 & 0 & 0 & 154 & 0 \\
\hline 2004 & 184 & 184 & 184 & 99 & 99 & 0 & 158 & 184 \\
\hline 2005 & 61 & 184 & 184 & 57 & 57 & 0 & 123 & 178 \\
\hline 2006 & 0 & 184 & 184 & 156 & 156 & 0 & 153 & 184 \\
\hline 2007 & 25 & 144 & 184 & 184 & 184 & 138 & 156 & 184 \\
\hline 2008 & 126 & 92 & 90 & 121 & 121 & 0 & 104 & 179 \\
\hline 2009 & 0 & 0 & 0 & 0 & 0 & 0 & 0 & 129 \\
\hline \multicolumn{9}{|c|}{ Effective runoff [m summer $\left.{ }^{-1}\right]$} \\
\hline 2001 & 1.21 & 1.16 & - & - & - & - & 0.11 & - \\
\hline 2002 & 1.16 & 1.78 & - & - & - & - & 0.11 & - \\
\hline 2003 & 0.95 & 1.94 & 1.39 & - & - & - & 0.16 & - \\
\hline 2004 & 0.82 & 0.92 & 0.70 & 0.13 & 0.03 & - & 0.10 & 0.11 \\
\hline 2005 & 0.82 & 1.53 & 1.24 & 0.18 & 0.05 & - & 0.10 & 0.21 \\
\hline 2006 & - & 1.32 & 1.09 & 0.20 & 0.08 & - & 0.17 & 0.20 \\
\hline 2007 & 0.40 & 0.93 & 0.94 & 0.22 & 0.04 & 0.12 & 0.11 & 0.15 \\
\hline 2008 & 1.03 & 1.26 & 1.26 & 0.30 & 0.06 & - & 0.18 & 0.17 \\
\hline 2009 & - & - & - & - & - & - & - & 0.16 \\
\hline mean & 0.99 & 1.44 & 1.02 & 0.22 & 0.06 & 0.09 & 0.14 & 0.17 \\
\hline \multicolumn{9}{|c|}{ SSC measurement days during summer (\#) } \\
\hline 2001 & 0 & 130 & 0 & 0 & 0 & 0 & 0 & 0 \\
\hline 2002 & 0 & 119 & 0 & 0 & 0 & 0 & 0 & 0 \\
\hline 2003 & 77 & 60 & 92 & 0 & 0 & 0 & 0 & 24 \\
\hline 2004 & 0 & 54 & 184 & 2 & 2 & 0 & 0 & 180 \\
\hline 2005 & 0 & 125 & 184 & 52 & 52 & 0 & 92 & 182 \\
\hline 2006 & 87 & 0 & 184 & 144 & 144 & 0 & 121 & 183 \\
\hline 2007 & 19 & 0 & 184 & 146 & 170 & 136 & 110 & 184 \\
\hline 2008 & 31 & 0 & 132 & 121 & 121 & 0 & 56 & 177 \\
\hline 2009 & 0 & 0 & 0 & 0 & 0 & 0 & 0 & 129 \\
\hline \multicolumn{9}{|c|}{ Average summer SSC $\left[\mathrm{g} \mathrm{l}^{-1}\right]$} \\
\hline 2001 & - & 0.29 & - & - & - & - & - & - \\
\hline 2002 & - & 0.32 & - & - & - & - & - & - \\
\hline 2003 & 0.91 & 0.33 & 0.19 & - & - & - & - & 0.24 \\
\hline 2004 & - & 0.60 & 0.29 & 0.13 & 0.33 & - & - & 1.63 \\
\hline 2005 & - & 0.29 & 0.97 & 1.14 & 0.96 & - & 3.69 & 4.03 \\
\hline 2006 & 0.95 & - & 0.47 & 1.39 & 3.64 & - & 2.84 & 2.66 \\
\hline 2007 & 3.04 & - & 1.47 & 1.31 & 1.87 & 1.85 & 1.90 & 1.75 \\
\hline 2008 & 2.27 & - & 0.81 & 1.64 & 2.26 & - & 2.73 & 1.67 \\
\hline 2009 & - & - & - & - & - & - & - & 1.49 \\
\hline mean & 0.93 & 0.29 & 0.80 & 1.45 & 2.59 & 1.85 & 2.37 & 2.20 \\
\hline
\end{tabular}


Table A1. Continued.

\begin{tabular}{|c|c|c|c|c|c|c|c|c|}
\hline \multirow[t]{2}{*}{ Year } & \multicolumn{4}{|c|}{ Tributaries } & \multicolumn{4}{|c|}{ Sutlej River at } \\
\hline & Ganvi & Wanger & Baspa & Spiti & Khab & Jangi & Karchham & Wangtoo \\
\hline \multicolumn{9}{|c|}{ 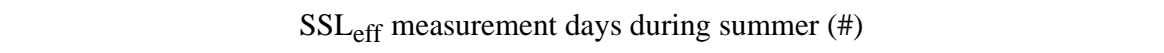 } \\
\hline 2001 & 0 & 130 & 0 & 0 & 0 & 0 & 0 & 0 \\
\hline 2002 & 0 & 119 & 0 & 0 & 0 & 0 & 0 & 0 \\
\hline 2003 & 75 & 60 & 92 & 0 & 0 & 0 & 0 & 0 \\
\hline 2004 & 0 & 54 & 184 & 2 & 2 & 0 & 0 & 180 \\
\hline 2005 & 0 & 125 & 184 & 52 & 52 & 0 & 46 & 177 \\
\hline 2006 & 0 & 0 & 184 & 144 & 144 & 0 & 102 & 183 \\
\hline 2007 & 0 & 0 & 184 & 146 & 170 & 136 & 93 & 184 \\
\hline 2008 & 30 & 0 & 90 & 121 & 121 & 0 & 46 & 177 \\
\hline 2009 & 0 & 0 & 0 & 0 & 0 & 0 & 0 & 129 \\
\hline \multicolumn{9}{|c|}{ Effective suspended sediment load [ $\left.\mathrm{t} \mathrm{summer}^{-1}\right]$} \\
\hline 2001 & - & 0.14 & - & - & - & - & - & - \\
\hline 2002 & - & 0.22 & - & - & - & - & - & - \\
\hline 2003 & 0.18 & 0.20 & 0.30 & - & - & - & - & - \\
\hline 2004 & - & 0.19 & 0.33 & 0.16 & 0.11 & - & - & 13.93 \\
\hline 2005 & - & 0.20 & 2.44 & 5.78 & 2.25 & - & 4.61 & 67.19 \\
\hline 2006 & - & - & 0.81 & 5.02 & 16.92 & - & 36.31 & 42.01 \\
\hline 2007 & - & - & 3.13 & 6.04 & 3.48 & 13.53 & 15.34 & 19.78 \\
\hline 2008 & 0.31 & - & 1.79 & 8.08 & 4.92 & - & 29.02 & 20.18 \\
\hline 2009 & - & - & - & - & - & - & - & 15.07 \\
\hline mean & 0.18 & 0.19 & 1.47 & 6.23 & 6.89 & 13.53 & 25.83 & 29.69 \\
\hline \multicolumn{9}{|c|}{ Effective suspended sediment yield $\left[\mathrm{t} \mathrm{km}^{-2}\right.$ summer $\left.^{-1}\right]$} \\
\hline 2001 & - & 457.6 & - & - & - & - & - & - \\
\hline 2002 & - & 695.0 & - & - & - & - & - & - \\
\hline 2003 & 1507.4 & 657.9 & 303.3 & - & - & - & - & - \\
\hline 2004 & - & 610.1 & 331.5 & 13.0 & 3.5 & - & - & 288.2 \\
\hline 2005 & - & 647.9 & 2464.7 & 463.0 & 72.6 & - & 99.3 & 1390.7 \\
\hline 2006 & - & - & 819.7 & 402.2 & 546.5 & - & 781.9 & 869.5 \\
\hline 2007 & - & - & 3163.1 & 484.2 & 112.3 & 302.4 & 330.4 & 409.4 \\
\hline 2008 & 2657.9 & - & 1806.2 & 647.5 & 158.9 & - & 624.9 & 417.7 \\
\hline 2009 & - & - & - & - & - & - & - & 312.0 \\
\hline mean & 1507.4 & 613.7 & 1717.1 & 499.2 & 222.6 & 302.4 & 556.2 & 614.6 \\
\hline
\end{tabular}


Table A2. List of earthquakes in the study area. Data provided by the Incorporated Research Institutions for Seismology (http://www.iris.washington.edu). Abbreviations of the magnitude types indicate the moment magnitude (MW), body-wave magnitude (MB), and surface-wave magnitude (MS). Abbreviations of the earthquake catalogues indicate the Bulletin of the International Seismological Centre (ISCCD), Quick Epicenter Determinations (QED), Monthly Hypocenter Data File (MHDF), Weekly Hypocenter Data File (WHDF), a list distributed by the National Earthquake Information Service (FINGER), and historical earthquake data listed in a hydropower project report (www.powermin.nic.in/whats_new/PFR/HP/Luhri_Hep.pdf).

\begin{tabular}{|c|c|c|c|c|c|c|c|}
\hline Date & Time & Latitude & Longitude & Depth & Magnitude & Type & Catalog \\
\hline 4 Apr 2011 & $11: 31: 40$ & 29.68 & 80.75 & 12.5 & 5.4 & M & FINGER/NEIC \\
\hline 6 Jul 2010 & 19:08:26 & 29.84 & 80.40 & 32.8 & 5.2 & $\mathrm{MB}$ & WHDF/NEIC \\
\hline 22 Jun 2010 & $23: 14: 11$ & 29.87 & 80.43 & 16.3 & 5.2 & MB & WHDF/NEIC \\
\hline 28 May 2010 & $07: 25: 03$ & 31.14 & 77.84 & 18.8 & 5.0 & MB & WHDF/NEIC \\
\hline $18 \operatorname{Mar} 2010$ & $07: 52: 29$ & 34.33 & 81.76 & 37.2 & 5.0 & $\mathrm{MB}$ & WHDF/NEIC \\
\hline 15 Mar 2010 & $20: 17: 17$ & 30.53 & 81.88 & 17.8 & 5.0 & $\mathrm{MB}$ & WHDF/NEIC \\
\hline 20 Nov 2009 & 07:16:59 & 30.76 & 83.45 & 19.0 & 5.1 & $\mathrm{MB}$ & MHDF/NEIC \\
\hline 29 Sep 2009 & 06:01:13 & 30.89 & 83.49 & 10.0 & 5.0 & $\mathrm{MB}$ & MHDF/NEIC \\
\hline 21 Sep 2009 & $09: 43: 51$ & 30.88 & 79.06 & 52.3 & 5.0 & $\mathrm{MB}$ & MHDF/NEIC \\
\hline 4 Jun 2009 & $02: 54: 48$ & 32.78 & 81.76 & 7.2 & 5.2 & $\mathrm{MB}$ & MHDF/NEIC \\
\hline 1 Apr 2009 & $02: 34: 37$ & 33.66 & 82.44 & 10.0 & 5.0 & MW & MHDF/NEIC \\
\hline 18 Feb 2009 & $10: 11: 44$ & 30.67 & 83.86 & 35.0 & 5.1 & MW & MHDF/NEIC \\
\hline 8 Dec 2008 & 08:59:09 & 29.99 & 82.09 & 15.3 & 5.3 & $\mathrm{MB}$ & ISCCD/ISC \\
\hline 25 Sep 2008 & $01: 47: 12$ & 30.84 & 83.59 & 10.0 & 5.4 & $\mathrm{MB}$ & ISCCD/ISC \\
\hline 25 Aug 2008 & $14: 16: 03$ & 30.82 & 83.56 & 7.6 & 5.1 & $\mathrm{MB}$ & ISCCD/ISC \\
\hline 25 Aug 2008 & $13: 39: 39$ & 30.93 & 83.46 & 10.0 & 5.1 & $\mathrm{MB}$ & ISCCD/ISC \\
\hline 25 Aug 2008 & $13: 22: 02$ & 31.06 & 83.65 & 25.5 & 6.6 & MS & ISCCD/ISC \\
\hline 5 May 2007 & $08: 51: 40$ & 34.27 & 82.03 & 14.2 & 5.7 & MB & ISCCD/ISC \\
\hline 14 Dec 2005 & 07:09:52 & 30.51 & 79.25 & 36.9 & 5.4 & ML & ISCCD/ISC \\
\hline 8 Apr 2005 & $19: 51: 42$ & 30.48 & 83.62 & 60.0 & 5.0 & $\mathrm{MB}$ & QED/NEIC \\
\hline 7 Apr 2005 & 20:04:40 & 30.52 & 83.66 & 14.7 & 6.1 & MS & ISCCD/ISC \\
\hline 26 Oct 2004 & $02: 11: 31$ & 31.04 & 81.08 & 4.0 & 5.9 & $\mathrm{MB}$ & ISCCD/ISC \\
\hline 28 Jul 2004 & $22: 22: 18$ & 30.64 & 83.60 & 51.0 & 5.1 & MB & QED/NEIC \\
\hline $11 \mathrm{Jul} 2004$ & $23: 08: 42$ & 30.72 & 83.67 & 8.1 & 6.2 & MS & ISCCD/ISC \\
\hline 4 Jun 2002 & $14: 36: 03$ & 30.57 & 81.42 & 10.0 & 5.4 & MB & ISCCD/ISC \\
\hline 27 Nov 2001 & $17: 56: 57$ & 29.55 & 81.75 & 42.7 & 5.0 & MB & ISCCD/ISC \\
\hline 27 Nov 2001 & $08: 53: 54$ & 29.55 & 81.75 & 33.0 & 5.3 & MS & MHDF/NEIC \\
\hline 27 Nov 2001 & $07: 31: 52$ & 29.61 & 81.75 & 33.0 & 5.6 & $\mathrm{MB}$ & MHDF/NEIC \\
\hline 17 Jun 2000 & $16: 34: 13$ & 32.00 & 78.41 & 38.8 & 5.6 & MS & ISCCD/ISC \\
\hline 6 Apr 1999 & $19: 37: 24$ & 30.48 & 79.56 & 16.5 & 5.5 & $\mathrm{MB}$ & ISCCD/NDI \\
\hline 28 Mar 1999 & 19:36:09 & 30.31 & 79.36 & 36.3 & 6.1 & MS & ISCCD/ISC \\
\hline 28 Mar 1999 & 19:05:12 & 30.51 & 79.42 & 22.9 & 6.4 & $\mathrm{MB}$ & ISCCD/ISC \\
\hline 28 Mar 1999 & 19:04:50 & 30.72 & 75.13 & 33.0 & 5.9 & $\mathrm{MB}$ & ISCCD/DJA \\
\hline 5 Jan 1997 & $08: 47: 25$ & 29.87 & 80.56 & 24.9 & 5.3 & MS & ISCCD/ISC \\
\hline 20 Oct 1993 & $16: 15: 59$ & 28.69 & 82.25 & - & 5.1 & MB & ISCCD/ISC \\
\hline 15 Sep 1993 & 15:08:15 & 33.33 & 75.74 & 43.7 & 5.0 & $\mathrm{MB}$ & ISCCD/ISC \\
\hline 9 Dec 1991 & 01:02:42 & 29.51 & 81.61 & 2.9 & 5.6 & $\mathrm{MB}$ & ISCCD/ISC \\
\hline 19 Oct 1991 & $21: 23: 15$ & 30.77 & 78.79 & 13.2 & 6,4 & $\mathrm{MB}$ & ISCCD/ISC \\
\hline 21 Sep 1990 & 16:08:19 & 29.98 & 79.91 & 18.7 & 5.1 & $\mathrm{MB}$ & ISCCD/ISC \\
\hline 9 Aug 1987 & $21: 15: 03$ & 29.47 & 83.74 & - & 5.5 & MB & ISCCD/ISC \\
\hline 16 Jul 1986 & 22:03:07 & 31.05 & 78.00 & 4.4 & 5.1 & MS & ISCCD/ISC \\
\hline 6 Jul 1986 & $19: 24: 23$ & 34.45 & 80.20 & 9.0 & 5.7 & $\mathrm{MB}$ & ISCCD/ISC \\
\hline 26 Apr 1986 & $07: 35: 16$ & 32.15 & 76.40 & 33.0 & 5.2 & MS & ISCCD/ISC \\
\hline 18 Nov 1984 & $22: 04: 36$ & 28.67 & 83.32 & - & 5.4 & $\mathrm{MB}$ & ISCCD/ISC \\
\hline 18 Мay 1984 & $04: 28: 52$ & 29.52 & 81.79 & - & 5.6 & $\mathrm{MB}$ & ISCCD/ISC \\
\hline 14 Mar 1984 & $15: 32: 33$ & 34.23 & 79.63 & 22.2 & 5.1 & MB & ISCCD/ISC \\
\hline 14 Mar 1984 & $01: 32: 11$ & 29.18 & 81.12 & 14.8 & 5.0 & $\mathrm{MB}$ & ISCCD/ISC \\
\hline 19 Feb 1984 & $15: 46: 26$ & 29.84 & 80.54 & 21.0 & 5.1 & $\mathrm{MB}$ & ISCCD/ISC \\
\hline 27 Feb 1983 & $20: 33: 07$ & 32.60 & 78.57 & 40.0 & 5.3 & $\mathrm{MB}$ & ISCCD/ISC \\
\hline 25 Jan 1982 & $17: 26: 17$ & 31.58 & 82.25 & 33.0 & 5.1 & $\mathrm{MB}$ & ISCCD/ISC \\
\hline 23 Jan 1982 & 17:48:02 & 31.56 & 82.21 & 30.9 & 5,3 & $\mathrm{MB}$ & ISCCD/ISC \\
\hline 23 Jan 1982 & $17: 37: 29$ & 31.68 & 82.28 & 25.0 & 6.0 & MB & ISCCD/ISC \\
\hline
\end{tabular}


Table A2. Continued.

\begin{tabular}{|c|c|c|c|c|c|c|c|}
\hline Date & Time & Latitude & Longitude & Depth & Magnitude & Type & Catalog \\
\hline 13 Jun 1981 & $00: 56: 57$ & 31.82 & 78.46 & 33.0 & 5,0 & $\mathrm{MB}$ & ISCCD/ISC \\
\hline 28 Мay 1981 & $23: 14: 05$ & 31.83 & 78.44 & - & 5.2 & MB & ISCCD/ISC \\
\hline 15 May 1981 & $17: 22: 43$ & 29.46 & 81.93 & 33.0 & 5.1 & $\mathrm{MB}$ & ISCCD/ISC \\
\hline 13 May 1981 & 02:07:52 & 32.58 & 82.36 & - & 5.0 & $\mathrm{MB}$ & ISCCD/ISC \\
\hline 6 Mar 1981 & $05: 58: 48$ & 29.80 & 80.66 & 23.6 & 5.1 & $\mathrm{MB}$ & ISCCD/ISC \\
\hline 23 Aug 1980 & 21:50:01 & 32.90 & 75.80 & 12.5 & 5.2 & $\mathrm{MB}$ & ISCCD/ISC \\
\hline 29 Jul 1980 & $14: 58: 42$ & 29.63 & 81.09 & - & 6.5 & MS & ISCCD/ISC \\
\hline 29 Jul 1980 & $12: 23: 08$ & 29.34 & 81.21 & 3.0 & 5.7 & $\mathrm{MB}$ & ISCCD/ISC \\
\hline 22 Jun 1980 & $14: 38: 53$ & 30.13 & 81.77 & - & 5.1 & $\mathrm{MB}$ & ISCCD/ISC \\
\hline 28 Dec 1979 & $01: 59: 18$ & 30.82 & 78.57 & 23.0 & 5.0 & $\mathrm{MB}$ & ISCCD/ISC \\
\hline 20 Мay 1979 & $22: 59: 12$ & 29.93 & 80.27 & - & 5.7 & $\mathrm{MB}$ & ISCCD/ISC \\
\hline 8 Aug 1978 & $10: 12: 29$ & 32.27 & 83.10 & 3.3 & 5.1 & $\mathrm{MB}$ & ISCCD/ISC \\
\hline 14 Jun 1978 & $16: 12: 05$ & 32.24 & 76.61 & 6.7 & 5.0 & $\mathrm{MB}$ & ISCCD/ISC \\
\hline 4 Apr 1978 & 00:40:29 & 32.98 & 82.26 & - & 5.5 & $\mathrm{MB}$ & ISCCD/ISC \\
\hline 27 Mar 1977 & $05: 36: 49$ & 32.67 & 78.66 & 26.0 & 5.1 & $\mathrm{MB}$ & ISCCD/ISC \\
\hline 19 Feb 1977 & $06: 15: 25$ & 31.80 & 78.43 & 40.0 & 5.4 & $\mathrm{MB}$ & ISCCD/ISC \\
\hline 8 Sep 1976 & $20: 13: 01$ & 32.03 & 78.76 & - & 5.3 & $\mathrm{MB}$ & ISCCD/ISC \\
\hline 6 Jul 1976 & $02: 55: 49$ & 32.44 & 78.35 & 24.6 & 5.1 & $\mathrm{MB}$ & ISCCD/ISC \\
\hline 10 May 1976 & $18: 43: 53$ & 29.33 & 81.46 & - & 5.2 & $\mathrm{MB}$ & ISCCD/ISC \\
\hline 5 Feb 1976 & $12: 04: 31$ & 31.24 & 77.03 & 5.5 & 5.0 & $\mathrm{MB}$ & ISCCD/ISC \\
\hline 7 Jan 1976 & $00: 24: 53$ & 32.97 & 76.12 & 40.3 & 5.3 & $\mathrm{MB}$ & ISCCD/ISC \\
\hline 11 Dec 1975 & 10:09:50 & 33.00 & 76.17 & 42.0 & 5.0 & $\mathrm{MB}$ & ISCCD/ISC \\
\hline 10 Dec 1975 & 03:26:06 & 32.95 & 76.10 & 4.5 & 5.3 & $\mathrm{MB}$ & ISCCD/ISC \\
\hline 5 Dec 1975 & $07: 37: 10$ & 33.10 & 76.13 & 23.8 & 5.3 & $\mathrm{MB}$ & ISCCD/ISC \\
\hline 5 Nov 1975 & $00: 35: 57$ & 32.07 & 78.74 & 21.1 & 5.0 & MB & ISCCD/ISC \\
\hline 6 Sep 1975 & $04: 44: 33$ & 29.21 & 81.95 & - & 5.1 & MB & ISCCD/ISC \\
\hline 29 Jul 1975 & $02: 40: 51$ & 32.57 & 78.49 & - & 5.5 & $\mathrm{MB}$ & ISCCD/ISC \\
\hline 19 Jul 1975 & $06: 10: 54$ & 31.95 & 78.59 & - & 5.1 & $\mathrm{MB}$ & ISCCD/ISC \\
\hline 2 Feb 1975 & $19: 14: 10$ & 32.55 & 78.50 & 21.0 & 5.1 & $\mathrm{MB}$ & ISCCD/ISC \\
\hline 19 Jan 1975 & $08: 12: 10$ & 31.94 & 78.52 & 48.6 & 5.8 & $\mathrm{MB}$ & ISCCD/ISC \\
\hline 19 Jan 1975 & 08:01:58 & 32.39 & 78.50 & 1.4 & 6.2 & $\mathrm{MB}$ & ISCCD/ISC \\
\hline 19 Jan 1975 & 08:00:18 & 32.30 & 78.66 & - & 5.1 & $\mathrm{MB}$ & ISCCD/ISC \\
\hline 23 Dec 1974 & $09: 45: 42$ & 29.32 & 81.38 & 45.0 & 5.2 & $\mathrm{MB}$ & ISCCD/ISC \\
\hline 16 Dec 1973 & 19:09:47 & 34.27 & 74.05 & 40.0 & 5.1 & $\mathrm{MB}$ & ISCCD/ISC \\
\hline 24 Oct 1973 & $05: 23: 51$ & 33.15 & 75.92 & 36.9 & 5.3 & $\mathrm{MB}$ & ISCCD/ISC \\
\hline 16 Jan 1973 & $21: 31: 26$ & 33.29 & 75.83 & 39.2 & 5.1 & $\mathrm{MB}$ & ISCCD/ISC \\
\hline 6 Sep 1972 & $02: 51: 28$ & 32.49 & 78.51 & 14.0 & 5.0 & $\mathrm{MB}$ & ISCCD/ISC \\
\hline 17 Aug 1972 & $18: 14: 25$ & 30.75 & 78.42 & 33.0 & 5.2 & $\mathrm{MB}$ & ISCCD/ISC \\
\hline 15 Mar 1972 & 06:00:30 & 30.53 & 84.43 & - & 5.1 & $\mathrm{MB}$ & ISCCD/ISC \\
\hline 4 Feb 1972 & $14: 08: 22$ & 30.34 & 84.47 & 18.0 & 5.1 & $\mathrm{MB}$ & ISCCD/ISC \\
\hline 3 May 1971 & $00: 33: 25$ & 30.79 & 84.33 & - & 5.3 & $\mathrm{MB}$ & ISCCD/ISC \\
\hline 12 Feb 1970 & $01: 51: 48$ & 29.24 & 81.57 & - & 5,3 & $\mathrm{MB}$ & ISCCD/ISC \\
\hline 22 Jun 1969 & $01: 33: 23$ & 30.50 & 79.40 & - & 5.3 & $\mathrm{MB}$ & ISCCD/ISC \\
\hline 5 Mar 1969 & $11: 14: 58$ & 29.46 & 81.02 & 22.0 & 5.0 & $\mathrm{MB}$ & ISCCD/ISC \\
\hline 3 Mar 1969 & $06: 20: 21$ & 30.04 & 79.84 & 18.0 & 5.1 & $\mathrm{MB}$ & ISCCD/ISC \\
\hline 13 Feb 1969 & $06: 48: 36$ & 28.50 & 75.70 & 33.0 & 5.1 & - & ISCCD/LAO \\
\hline 31 May 1968 & 03:01:36 & 29.91 & 79.92 & 33.0 & 5.0 & $\mathrm{MB}$ & ISCCD/ISC \\
\hline 11 Feb 1968 & $20: 38: 27$ & 34.15 & 78.70 & 24.0 & 5.1 & MB & ISCCD/ISC \\
\hline 5 Jan 1968 & $06: 42: 44$ & 30.41 & 79.25 & 7.0 & 5.0 & $\mathrm{MB}$ & ISCCD/ISC \\
\hline 18 Dec 1967 & $10: 51: 36$ & 29.46 & 81.71 & 42.0 & 5.0 & $\mathrm{MB}$ & ISCCD/ISC \\
\hline 20 Feb 1967 & $15: 18: 39$ & 33.63 & 75.33 & 20.0 & 5.5 & $\mathrm{MB}$ & ISCCD/ISC \\
\hline 21 Dec 1966 & $22: 10: 59$ & 29.65 & 80.79 & 21.0 & 5.3 & $\mathrm{MB}$ & ISCCD/ISC \\
\hline 16 Dec 1966 & $20: 52: 16$ & 29.62 & 80.79 & - & 5,7 & $\mathrm{MB}$ & ISCCD/ISC \\
\hline 15 Aug 1966 & $02: 15: 28$ & 28.67 & 78.93 & 5.0 & 5.6 & $\mathrm{MB}$ & ISCCD/ISC \\
\hline 5 Aug 1966 & 01:03:02 & 32.76 & 79.61 & - & 5.2 & $\mathrm{MB}$ & ISCCD/ISC \\
\hline 29 Jun 1966 & $00: 42: 10$ & 29.69 & 80.86 & 21.0 & 5.1 & $\mathrm{MB}$ & ISCCD/ISC \\
\hline 27 Jun 1966 & $13: 55: 49$ & 29.62 & 80.93 & - & 5.3 & $\mathrm{MB}$ & ISCCD/ISC \\
\hline
\end{tabular}


Table A2. Continued.

\begin{tabular}{lccrrrll}
\hline Date & Time & Latitude & Longitude & Depth & Magnitude & Type & Catalog \\
\hline 27 Jun 1966 & $11: 21: 42$ & 29.57 & 80.82 & 26.0 & 5.2 & MB & ISCCD/ISC \\
27 Jun 1966 & $10: 59: 18$ & 29.71 & 80.89 & - & 6.0 & MB & ISCCD/ISC \\
27 Jun 1966 & $10: 49: 51$ & 29.50 & 80.90 & 72.0 & 5.4 & MB & ISCCD/ISC \\
27 Jun 1966 & $10: 47: 45$ & 29.55 & 80.99 & 43.0 & 5.3 & MB & ISCCD/ISC \\
27 Jun 1966 & $10: 41: 08$ & 29.62 & 80.83 & 33.0 & 6.0 & MB & ISCCD/ISC \\
6 Mar 1966 & $02: 15: 57$ & 31.49 & 80.50 & 50.0 & 6.0 & MB & ISCCD/ISC \\
6 Mar 1966 & $02: 10: 52$ & 31.51 & 80.55 & 5.0 & 5.4 & MB & ISCCD/ISC \\
11 Oct 1965 & $20: 15: 15$ & 33.80 & 78.20 & 33.0 & 5.2 & - & ISCCD/QUE \\
1 Jun 1965 & $07: 52: 25$ & 28.59 & 83.06 & 20.0 & 5.3 & MB & ISCCD/ISC \\
31 May 1965 & $02: 04: 43$ & 32.65 & 77.99 & 28.0 & 5.2 & MB & ISCCD/ISC \\
20 Apr 1965 & $05: 15: 30$ & 33.86 & 82.10 & 89.0 & 5.8 & MB & ISCCD/ISC \\
18 Mar 1965 & $02: 41: 30$ & 29.55 & 80.26 & 67.0 & 5.0 & MB & ISCCD/ISC \\
20 Dec 1964 & $03: 31: 32$ & 29.35 & 81.10 & 9.0 & 5.3 & MB & ISCCD/ISC \\
2 Dec 1964 & $08: 21: 42$ & 29.58 & 81.10 & 3.0 & 5.2 & MB & ISCCD/ISC \\
6 Oct 1964 & $20: 19: 32$ & 29.40 & 80.98 & 11.0 & 5.3 & MB & ISCCD/ISC \\
26 Sep 1964 & $00: 46: 03$ & 29.96 & 80.46 & 50.0 & 5.9 & MB & ISCCD/ISC \\
24 May 1964 & $00: 00: 48$ & 30.04 & 82.18 & 23.0 & 5.1 & MB & ISCCD/ISC \\
17 Jun 1962 & $00: 00: 00$ & 33.74 & 75.83 & 88.0 & 5.5 & - & HEP \\
10 Jul 1947 & $00: 00: 00$ & 32.60 & 75.90 & - & 6.0 & - & HEP \\
10 Jul 1946 & $00: 00: 00$ & 32.60 & 75.90 & - & 6.0 & - & HEP \\
22 Jun 1945 & $00: 00: 00$ & 32.50 & 76.00 & - & 6.5 & - & HEP \\
21 Nov 1939 & $00: 00: 00$ & 36.50 & 74.00 & - & 6.9 & - & HEP \\
28 Feb 1906 & $00: 00: 00$ & 32.00 & 77.00 & - & 7.0 & - & HEP \\
4 Apr 1905 & $00: 00: 00$ & 32.30 & 76.20 & 25.0 & 8.0 & - & HEP \\
\hline
\end{tabular}

Acknowledgements. This research was funded by the German Science Foundation (DFG, GRK 1364). The data used in this study were acquired as part of the Tropical Rainfall Measuring Mission (TRMM) sponsored by the Japan National Space Development Agency (NASDA) and the NASA. B. B. was supported with grants from NASA (NNX08AG05G) and NSF (EAR 0819874). D. S. was supported by the German Federal Ministry of Education and Research (BMBF, PROGRESS). We thank S. Kumar, C. Kumar, V. Negi, H. Negi, K. Srinivasan, D. P. Goel, S. Pathak, D. Shukla, who provided suspended sediment concentration and river discharge records for us. We are grateful to Tashi Longpo, Swami Ray, and Bishan Lal for their enduring support during fieldwork. We appreciated thoughtful comments by two anonymous reviewers that improved the presentation of this study.

Edited by: M. Mikos

\section{References}

Ali, K. F. and De Boer, D. H.: Spatial patterns and variation of suspended sediment yield in the upper Indus River basin, northern Pakistan, J. Hydrol., 334, 368-387, 2007.

Andermann, C., Bonnet, S., and Gloaguen, R.: Evaluation of precipitation data sets along the Himalayan front, Geochem. Geophy. Geosy., 12, Q07023, doi:10.1029/2011gc003513, 2011.
Baker, V. R. and Kale, V. S.: The role of extreme events in shaping bedrock channels, in: In Rivers Over Rock: Fluvial Processes in Bedrock Channels, edited by: Tinkler, K. J. and Wohl, E. E., Geophysics Monogrograph Series, Washington, D.C., 153-165, 1998.

Barnard, P. L., Owen, L. A., Sharma, M. C., and Finkel, R. C.: Natural and human-induced landsliding in the Garhwal Himalaya of northern India Geomorphology, 40, 21-35, 2001.

Bhambri, R. and Bolch, T.: Glacier mapping: a review with special reference to the Indian Himalayas, Prog. Phys. Geogr., 33, 672704, 2009.

Bhutiyani, M.: Sediment load characteristics of a proglacial stream of Siachen Glacier and the erosion rate in Nubra valley in the Karakoram Himalayas, India, J. Hydrol., 227, 84-92, 2000.

Bierman, P. R.: Using in situ produced cosmogenic isotopes to estimate rates of landscape evolution: A review from the geomorphic perspective, J. Geophys. Res.-Solid, 99, 13885-13896, 1994.

Bilham, R., Gaur, V. K., and Molnar, P.: Earthquakes Himalayan seismic hazard, Science, 293, 1442-1444, doi:10.1126/science.1062584, 2001.

Bookhagen, B.: Appearance of extreme monsoonal rainfall events and their impact on erosion in the Himalaya, Geomatics, Nat. Hazards Risk, 1, 37-50, 2010.

Bookhagen, B. and Burbank, D. W.: Topography, relief, and TRMM-derived rainfall variations along the Himalaya, Geophys. Res. Lett., 33, L08405, doi:10.1029/2006GL026037, 2006. 
Bookhagen, B. and Burbank, D. W.: Toward a complete Himalayan hydrological budget: Spatiotemporal distribution of snowmelt and rainfall and their impact on river discharge, J. Geophys. Res., 115, F03019, doi:10.1029/2009JF001426, 2010.

Bookhagen, B. and Strecker, M.: Spatiotemporal trends in erosion rates across a pronounced rainfall gradient: examples from the south-central Andes, Earth Planet. Sc. Lett., 327-328, 97-110, 2012.

Bookhagen, B., Thiede, R. C., and Strecker, M. R.: Abnormal monsoon years and their control on erosion and sediment flux in the high, arid northwest Himalaya, Earth Planet. Sc. Lett., 231, 131146, 2005.

Bookhagen, B., Fleitmann, D., Nishiizumi, K., Strecker, M. R., and Thiede, R. C.: Holocene monsoonal dynamics and fluvial terrace formation in the northwest Himalaya, India, Geology, 34, 601604, 2006.

Burbank, D. W.: Mountain Uplift and Climate Change, in: Encyclopedia of Paleoclimatology and Ancient Environments, edited by: Gornitz, V., Springer, 596-606, 2009.

Burbank, D. W., Leland, J., Fielding, E., Anderson, R. S., Brozovic, N., Reid, M. R., and Duncan, C.: Bedrock incision, rock uplift and threshold hillslopes in the northwestern Himalayas, Nature, 379, 505-510, 1996.

Burbank, D. W., Blythe, A. E., Putkonen, J., Pratt-Sitaula, B., Gabet, E., Oskin, M., Barros, A., and Ojha, T. P.: Decoupling of erosion and precipitation in the Himalayas, Nature, 426, 652-655, 2003.

Burchfiel, B. C., Chen, Z., Hodges, K. V., Liu, Y., and Royden, L. H.: The South Tibetan Detachment System, Himalayan orogen: extension contemporaneous with and parallel to shortening in a collisional mountain, Geol. Soc. Am. Spec. Pap., 269, 1-42, 1992.

Burg, J. P., Nievergelt, P., Oberli, F., Seward, D., Davy, P., and Maurin, J.: The Namche Barwa syntaxis: evidence for exhumation related to compressional crustal folding, J. Southeast Asian Earth Sci., 16, 239-252, 1998.

Cayan, D. R., Redmond, K. T., and Riddle, L. G.: ENSO and Hydrologic Extremes in the Western United States, J. Climate, 12, 2881-2893, 1999.

Chakrapani, G. J. and Saini, R. K.: Temporal and spatial variations in water discharge and sediment load in the Alaknanda and Bhagirathi Rivers in Himalaya, India, J. Asian Earth Sci., 35, 545553, 2009.

Cheng, G. D. and Wu, T. H.: Responses of permafrost to climate change and their environmental significance, Qinghai-Tibet Plateau, J. Geophys. Res.-Earth, 112, F02S03, doi:10.1029/2006JF000631, 2007.

Clift, P. D., Shimizu, N., Layne, G. D., Blusztajn, J. S., Gaedicke, C., Schluter, H. U., Clark, M. K., and Amjad, S.: Development of the Indus Fan and its significance for the erosional history of the Western Himalaya and Karakoram, Geol. Soc. Am. Bull., 113, 1039-1051, 2001.

Clift, P. D., Hodges, K. V., Heslop, D., Hannigan, R., van Long, H., and Calves, G.: Correlation of Himalayan exhumation rates and Asian monsoon intensity, Nat. Geosci., 1, 875-880, 2008.

Collins, D. N. and Hasnain, S. I.: Runoff and sediment transport from giacierized basins at the Himalayan scale, Effects of Scale on Interpretation and Management of Sediment and Water Quality, Proceedings of a Boulder Symposium, July 1995, IAHS
Publ. no. 226, 17-25, 1995.

Coppus, R. and Imeson, A. C.: Extreme events controlling erosion and sediment transport in a semi-arid sub-andean valley, Earth Surf. Proc. Land., 27, 1365-1375, 2002.

Craddock, W. H., Burbank, D. W., Bookhagen, B., and Gabet, E. J.: Bedrock channel geometry along an orographic rainfall gradient in the upper Marsyandi River valley in central Nepal, J. Geophys. Res.-Earth, 112, F03007, doi:10.1029/2006JF000589, 2007.

Curray, J. R., Emmel, F. J., and Moore, D. G.: The Bengal Fan: morphology, geometry, stratigraphy, history and processes, Mar. Petrol. Geol., 19, 1191-1223, 2003.

Dadson, S. J., Hovius, N., Chen, H. G., Dade, W. B., Hsieh, M. L., Willett, S. D., Hu, J. C., Horng, M. J., Chen, M. C., Stark, C. P., Lague, D., and Lin, J. C.: Links between erosion, runoff variability and seismicity in the Taiwan orogen, Nature, 426, 648-651, doi:10.1038/nature02150, 2003.

Dahal, R. K. and Hasegawa, S.: Representative rainfall thresholds for landslides in the Nepal Himalaya, Geomorphology, 100, 429443, 2008.

Dozier, J., Painter, T. H., Rittger, K., and Frew, J. E.: Time-space continuity of daily maps of fractional snow cover and albedo from MODIS, Adv. Water Resour., 31, 1515-1526, 2008.

FAO: Land Cover Map of Himalaya Region, Food and Agriculture Organization of the United Nations (FAO), http://www.glcn.org/ databases/hima_landcover_en.jsp (last access: July 2012), Rome, 2009

Finlayson, D. P., Montgomery, D. R., and Hallet, B.: Spatial coincidence of rapid inferred erosion within young metamorphic massifs in the Himalayas, Geology, 30, 219-222, 2002.

Finnegan, N. J., Hallet, B., Montgomery, D. R., Zeitler, P. K., Stone, J. O., Anders, A. M., and Yuping, L.: Coupling of rock uplift and river incision in the Namche Barwa-Gyala Peri massif, Tibet, Geol. Soc. Am. Bull., 120, 142-155, 2008.

Fritsch, F. N. and Carlson, R. E.: Monotone Piecewise Cubic Interpolation, SIAM J. Numer. Anal., 7, 238-246, 1980.

Fuchs, G.: Contributions to the geology of the North-Western Himalayas, Abhandlungen der Geologischen Bundesanstalt, Vienna, 32, 1-59, 1975.

Gabet, E.: Rainfall thresholds for landsliding in the Himalayas of Nepal, Geomorphology, 63, 131-143, 2004.

Gabet, E. J., Burbank, D. W., Pratt-Sitaula, B., Putkonen, J., and Bookhagen, B.: Modern erosion rates in the High Himalayas of Nepal, Earth Planet. Sc. Lett., 267, 482-494, 2008.

Gafurov, A. and Bárdossy, A.: Cloud removal methodology from MODIS snow cover product, Hydrol. Earth Syst. Sci., 13, 13611373, doi:10.5194/hess-13-1361-2009, 2009.

Galy, A. and France-Lanord, C.: Higher erosion rates in the Himalaya: Geochemical constraints on riverine fluxes, Geology, 29, 23-26, 2001.

Gansser, A.: The Geology of the Himalayas, Wiley Interscience, New York, 1964.

Gardner, J. S. and Jones, N. K.: Sediment transport and yield in the Raikot glacier, in: Himalaya to the Sea: Geology, Geomorphology and the Quaternary, edited by: Shroder, J. F. and Shroder, J. F. J., Routledge, 2002.

Gupta, V. and Sah, M. P.: Impact of the Trans-Himalayan Landslide Lake Outburst Flood (LLOF) in the Satluj catchment, Himachal Pradesh, India, Nat. Hazards, 45, 379-390, 2007. 
Hall, D., Riggs, G. A., Salomonson, V. V., DiGirolamo, N. E., and Bayr, K. J.: MODIS snow-cover products, Remote Sens. Environ., 83, 181-194, 2002.

Hall, D. K., Riggs, G. A., and Salomonson, V. V.: Development of Methods for Mapping Global Snow Cover Using Moderate Resolution Imaging Spectroradiometer Data, Remote Sens. Environ., 54, 127-140, 1995.

Haritashya, U. K., Singh, P., Kumar, N., and Gupta, R. P.: Suspended sediment from the Gangotri Glacier: Quantification, variability and associations with discharge and air temperature, J. Hydrol., 321, 116-130, 2006.

Hartshorn, K., Hovius, N., Dade, W. B., and Slingerland, R. L.: Climate-driven bedrock incision in an active mountain belt, Science, 297, 2036-2038, 2002.

Heim, A. and Gansser, A.: Central Himalaya Geological Observations of the Swiss Expedition 1936, Zurich, 1-246, 1939.

Heimsath, A. M. and McGlynn, R.: Quantifying periglacial erosion in the Nepal high Himalaya, Geomorphology, 97, 5-23, 2008.

Henck, A. C., Montgomery, D. R., Huntington, K. W., and Liang, C. A.: Monsoon control of effective discharge, Yunnan and Tibet, Geology, 38, 975-978, 2010.

Hintersberger, E., Thiede, R., Strecker, M., and Hacker, B.: Eastwest extension in the NW Indian Himalaya, Geol. Soc. Am. Bull., 122, 1499-1515, 2010.

Hodges, K. V.: Tectonics of the Himalaya and southern Tibet from two perspectives, Geol. Soc. Am. Bull., 112, 324-350, 2000.

Hodges, K. V., Wobus, C., Ruhl, K., Schildgen, T., and Whipple, K.: Quaternary deformation, river steepening, and heavy precipitation at the front of the Higher Himalayan ranges, Earth Planet. Sc. Lett., 220, 379-389, 2004.

Hovius, N., Meunier, P., Lin, C.-W., Chen, H., Chen, Y.-G., Dadson, S., Horng, M.-J., and Lines, M.: Prolonged seismically induced erosion and the mass balance of a large earthquake, Earth Planet. Sc. Lett., 304, 347-355, 2011.

Huete, A., Didan, K., Miura, T., Rodriguez, E. P., Gao, X., and Ferreira, L. G.: Overview of the radiometric and biophysical performance of the MODIS vegetation indices, Remote Sens. Environ., 83, 195-213, 2002.

Huffman, G. J., Adler, R. F., Bolvin, D. T., Gu, G., Nelkin, E. J., Bowman, K. P., Hong, Y., Stocker, E. F., and Wolff, D. B.: The TRMM Multisatellite Precipitation Analysis (TMPA): QuasiGlobal, Multiyear, Combined-Sensor Precipitation Estimates at Fine Scales, J. Hydrometeorol., 8, 33-55, 2007.

IPCC: IPCC Fourth Assessment Report: Working Group II Report "Impacts, Adaptation and Vulnerability", in: Fourth Assessment Reportof the Intergovernmental Panel on Climate Change, edited by: Parry, M. L., Canziani, O. F., Palutikof, J. P., van der Linden, P. J., and Hanson, C. E., Cambridge University Press, 2007.

Jain, S. K., Singh, P., Saraf, A. K., and Seth, S. M.: Estimation of sediment yield for a rain, snow and glacier fed river in the Western Himalayan region, Water Resour. Manage., 17, 377393, 2003.

Jha, P. K., Subramanian, V., and Sitasawad, R.: Chemical and sediment mass transfer in the Yamuna River - A tributary of the Ganges system, J. Hydrol., 104, 237-246 1988.

Kirchner, J. W., Finkel, R. C., Riebe, C. S., Granger, D. E., Clayton, J. L., King, J. G., and Megahan, W. F.: Mountain erosion over $10 \mathrm{yr}, 10 \mathrm{k} . \mathrm{y} .$, and $10 \mathrm{~m} . \mathrm{y}$. time scales, Geology, 29, 591$594,2001$.
Klein, A. G. and Barnett, A. C.: Validation of daily MODIS snow cover maps of the Upper Rio Grande River Basin for the 20002001 snow year, Remote Sens. Environ., 86, 162-176, 2003.

Krishnamurthy, C. K. B., Lall, U., and Kwon, H.-H.: Changing Frequency and Intensity of Rainfall Extremes over India from 1951 to 2003, J. Climate, 22, 4737-4746, 2009.

Kumar, R., Bales, J. D., Jubach, R., Gyamba, P. D., Kane, M. D., and Scott, A. C.: Flash-Flood Warning for the Upper Sutlej River Basin, Northern India, http://cedb.asce.org/cgi/WWWdisplay. cgi?165529 (last access: January 2012), 2007.

Lal, D., Harris, N. B. W., Sharma, K. K., Gu, Z., Ding, L., Liu, T., Dong, W., Caffee, M. W., and Jull, A. J. T.: Erosion history of the Tibetan Plateau since the last interglacial: constraints from the first studies of cosmogenic ${ }^{10} \mathrm{Be}$ from Tibetan bedrock, Earth Planet. Sc. Lett., 217, 33-42, 2003.

Larson, K., Buergmann, R., Bilham, R., and Freymueller, J. T.: Kinematics of the India-Eurasia collision zone from GPS measurements, J. Geophys. Res., 104, 1077-1093, 1999.

Lawrence, D. M. and Slater, A. G.: A projection of severe nearsurface permafrost degradation during the 21 st century, Geophys. Res. Lett., 32, L24401, doi:10.1029/2005GL025080, 2005.

Meade, R. H.: Movement and storage of sediment in river systems, in: Physical and chemical weathering in geochemical cycles, edited by: Lerman, A. and Meybeek, M., Kluver, Dordrecht, 165-179, 1988.

Meigs, A., Krugh, W. C., Davis, K., and Bank, G.: Ultra-rapid landscape response and sediment yield following glacier retreat, Icy Bay, southern Alaska, Geomorphology, 78, 207-221, doi:10.1016/j.geomorph.2006.01.029, 2006.

Meunier, P., Hovius, N., and Haines, A. J.: Topographic site effects and the location of earthquake induced landslides. Earth Planet. Sc. Lett., 275, 221-232, 2008.

Miller, C., Kloetzli, U., Frank, W., Thoeni, M., and Grasemann, B.: Proterozoic crustal evolution in the NW Himalaya (India) as recorded by circa $1.80 \mathrm{Ga}$ mafic and $1.84 \mathrm{Ga}$ granitic magmatism, Precambrian Res., 103, 191-206, 2000.

Milliman, J. D. and Syvitski, J. P. M.: Geomorphic/Tectonic Control of Sediment Discharge to the Ocean: The Importance of Small Mountainous Rivers, J. Geol., 100, 525-544, 1992.

Molnar, P. and England, P.: Late Cenozoic uplift of mountain ranges and global climate change: chicken or egg?, Nature, 346, 29-34, 1990.

Molnar, P., Anderson, R. S., and Anderson, S. P.: Tectonics, fracturing of rock, and erosion, J. Geophys. Res., 112, 1-12, 2007.

Morgan, R. P. C.: Soil erosion and conservation, Wiley-Blackwell, 320 pp., 2004.

Ohta, T., Fukushima, Y., Suzuki, M., Motoyama, H., Kawashima, K., and Kubota, H.: Suspended sediment yield in a glaciated watershed of Langtang valley, Nepal Himalayas, Bull. Glacier Res., 5, 19-24, 1987.

Parajka, J. and Blöschl, G.: Validation of MODIS snow cover images over Austria, Hydrol. Earth Syst. Sci., 10, 679-689, doi:10.5194/hess-10-679-2006, 2006.

Pratt-Sitaula, B., Garde, M., Burbank, D. W., Oskin, M., Heimsath, A., and Gabet, E.: Bedload-to-suspended load ratio and rapid bedrock incision from Himalayan landslide-dam lake record, Quaternary Res., 68, 111-120, 2007. 
Puri, V. M. K.: Glaciohydrological and suspended sediment load studies in the melt water channel of Changme Khangpu Glacier, Mangam district, Sikkim, Symposium on Snow, Ice and Glaciers - Himalayan Prospective, Lucknow, 1999.

Rao, S. V. N., Rao, M. V., and Ramasasitri, K. S.: A Study of Sedimentation in Chenab Basin in Western Himalayas, Nord. Hydrol., 28, 201-216, 1997.

Raymo, M. E. and Ruddiman, W. F.: Tectonic forcing of late Cenozoic climate, Nature, 359, 117-122, 1992.

Raymo, M. E., Ruddiman, W. E., and Froelich, P. N.: Influence of late Cenozoic mountain building on ocean geochemical cycles, Geology, 16, 649-653, 1988.

Reiners, P. W., Ehlers, T. A., and Zeitler, P. K.: Past, Present, and Future of Thermochronology, Rev. Mineral. Geochem., 58, 1-18, 2005.

Scherler, D., Bookhagen, B., and Strecker, M. R.: Spatially variable response of Himalayan glaciers to climate change affected by debris cover, Nat. Geosci., 4, 156-159, doi:10.1038/ngeo1068, 2011a.

Scherler, D., Bookhagen, B., and Strecker, M. R.: Hillslopeglacier coupling: the interplay of topography and glacial dynamics in High Asia, J. Geophys. Res., 116, F02019, doi:10.1029/2010JF001751, 2011b.

Shekhar, M. S., Chand, H., Kumar, S., Srinivasan, K., and Ganju, A.: Climate-change studies in the western Himalaya, Ann. Glaciol., 51, 105-112, 2010.

Singh, P. and Kumar, N.: Effect of orography on precipitation in the western Himalayan region, J. Hydrol., 199, 183-206, 1997.

Singh, P., Ramasatri, K. S., Kumar, N., and Bhatnagar, N. K.: Suspended Sediment Transport from the Dokriani Glacier in the Garhwal Himalayas, Nord. Hydrol., 34, 221-244, 2003.

Sinha, R. and Friend, P. F.: River systems and their sediment flux, Indo-Gangetic plains, Northern Bihar, India, Sedimentology, 41, 825-845, 1994.

SJVNL: Concept paper on silt content in Satluj river, Satluj Jal Vidyut Nigam Limited, Satluj Jal Vidyut Nigam Limited, Shimla, India, 2005.

Small, E. E. and Anderson, R. S.: Geomorphically driven late Cenozoic rock uplift in the Sierra Nevada, California, Science, 270, 277-280, 1995.

Soja, R. and Starkel, L.: Extreme rainfalls in Eastern Himalaya and southern slope of Meghalaya Plateau and their geomorphologic impacts, Geomorphology, 84, 170-180, 2007.

Stewart, R. J., Hallet, B., Zeitler, P. K., Malloy, M. A., Allen, C. M., and Trippett, D.: Brahmaputra sediment flux dominated by highly localized rapid erosion from the easternmost Himalaya, Geology, 36, 711-714, 2008.

Thayyen, R. J., Gergan, J. T., and Dobhal, D. P.: Role of glaciers and snow cover on headwater river hydrology in monsoon regime - Micro-scale study of Din Gad catchment, Garhwal Himalaya, India, Current Sci., 92, 376-382, 2007.

Thiede, R. C., Bookhagen, B., Arrowsmith, J. R., Sobel, E. R., and Strecker, M. R.: Climatic control on rapid exhumation along the Southern Himalayan Front, Earth Planet. Sc. Lett., 222, 791-806, 2004.
Thiede, R. C., Arrowsmith, J. R., Bookhagen, B., McWilliams, M., Sobel, E. R., and Strecker, M. R.: Dome formation and extension in the Tethyan Himalaya, Leo Pargil, northwest India, Bull. Geol. Soc. Am., 118, 635-650, 2006.

Thiede, R. C., Ehlers, T. A., Bookhagen, B., and Strecker, M. R.: Erosional variability along the northwest Himalaya, J. Geophys. Res., 114, F01015, doi:10.1029/2008JF001010, 2009.

Vance, D., Bickle, M., Ivy-Ochs, S., and Kubik, P. W.: Erosion and exhumation in the Himalaya from cosmogenic isotope inventories of river sediments, Earth Planet. Sc. Lett., 206, 273-288, 2003.

Vannay, J.-C. and Grasemann, B.: Inverted metamorphism in the High Himalaya of Himachal Pradesh (NW India): Phase equilibria versus thermobarometry, Schweiz, Mineral. Petrogr. Mitt., 78, 107-132, 1998.

Vannay, J. C., Grasemann, B., Rahn, M., Frank, W., Carter, A., Baudraz, V., and Cosca, M.: Miocene to Holocene exhumation of metamorphic crustal wedges in the NW Himalaya: Evidence for tectonic extrusion coupled to fluvial erosion, Tectonics, 23, 1-24, 2004.

von Blanckenburg, F.: The control mechanisms of erosion and weathering at basin scale from cosmogenic nuclides in river sediment, Earth Planet. Sc. Lett., 237, 462-479, 2005.

Wang, Q., Zhang, P.-Z., Freymueller, J. T., Bilham, R., Larson, K. M., Lai, X. A., You, X., Niu, Z., Wu, J., Li, Y., Liu, J., Yang, Z., and Chen, Q.: Present-Day Crustal Deformation in China Constrained by Global Positioning System Measurements, Science, 294, 574-577, doi:10.1126/science.1063647, 2001.

Webb, A. A. G., Yin, A., Harrison, T. M., Celerier, J., Gehrels, G. E., Manning, C. E., and Grove, M.: Cenozoic tectonic history of the Himachal Himalaya (northwestern India) and its constraints on the formation mechanism of the Himalayan orogen, Geosphere, 7, 1013-1061, doi:10.1130/ges00627.1, 2011.

Wobus, C., Heimsath, A., Whipple, K., and Hodges, K.: Active outof-sequence thrust faulting in the central Nepalese Himalaya, Nature, 434, 1008-1011, 2005.

Wolman, M. G. and Miller, J. P.: Magnitude and frequency of forces in geomorphic processes, J. Geol., 68, 54-74, 1960.

Wulf, H., Bookhagen, B., and Scherler, D.: Seasonal precipitation gradients and their impact on fluvial sediment flux in the Northwest Himalaya, Geomorphology, 118, 13-21, doi:10.1016/J.Geomorph.2009.12.003, 2010.

Yatagai, A., Arakawa, O., Kamiguchi, K., Kawamoto, H., Nodzu, M. I., and Hamada, A.: A 44-Year Daily Gridded Precipitation Dataset for Asia Based on a Dense Network of Rain Gauges, Scientific Online Letters on the Atmosphere - SOLA, 5, 137140, 2009.

Zeitler, P. K., Melzer, A. S., Koons, P. O., Craw, D., Hallet, B., Chamberlain, C. P., Kidd, W. S. F., Park, S. K., Seeber, L., Bishop, M. P., and Shroder, J. F.: Erosion, Himalayan tectonics and the geomorphology of metamorphism, GSA Today, 11, 4-8, 2001.

Zhao, L., Ping, C. L., Yang, D. Q., Cheng, G. D., Ding, Y. J., and Liu, S. Y.: Changes of climate and seasonally frozen ground over the past 30 years in Qinghai-Xizang (Tibetan) Plateau, China, Global Planet. Change, 43, 19-31, 2004. 